\title{
Structures and Styles of Deformation in Rift, Ridge, Transform Zone, Oblique Rift and a Microplate Offshore/Onshore North Iceland
}

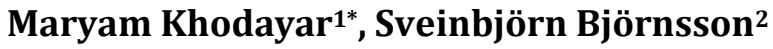 \\ ${ }^{1}$ Iceland GeoSurvey (ÍSOR), Reykjavík, Iceland \\ ${ }^{2}$ National Energy Authority (Orkustofnun), Reykjavík, Iceland \\ Email: ^mak@isor.is, ^Profnet10@gmail.com, svb@orkugardur.is
}

How to cite this paper: Khodayar, M. and Björnsson, S. (2018) Structures and Styles of Deformation in Rift, Ridge, Transform Zone, Oblique Rift and a Microplate Offshore/Onshore North Iceland. International Journal of Geosciences, 9, 461-511. https://doi.org/10.4236/ijg.2018.98029

Received: July 7, 2018

Accepted: August 28, 2018

Published: August 31, 2018

Copyright $\odot 2018$ by authors and Scientific Research Publishing Inc. This work is licensed under the Creative Commons Attribution-NonCommercial International License (CC BY-NC 4.0). http://creativecommons.org/licenses/by-nc/4.0/

\section{Abstract}

The diverging plate boundaries in North Iceland and its shelf display a complex tectonic at the Kolbeinsey Ridge (K-R), the Northern Rift Zone (NRZ), and the Tjörnes Fracture Zone containing the Grímsey Oblique Rift (GOR), the Húsavík-Flatey Fault (HFF), and the Dalvík Lineament (DL). While active deformation is well-known, the structural pattern is sporadically mapped and a comprehensive account of the upper Tertiary-present deformation is not fully at hand. To address the gaps, this paper provides new regional tectonic maps with continuous coverage, and detailed analyses of the deformation. Faults, open fractures, prominent joints and volcanic edifices were identified on Multibeam/Single beam, Spot 5, and Digital Elevation Model, and subjected to multidisciplinary structural analysis and correlation with selected data. Some of the results are: 1) Six sets constitute the structural pattern. The $\mathrm{N}-\mathrm{S}$ rift-parallel normal faults are $1 / 3$, and the shear fractures of the transform zone and the oblique rift $2 / 3$ of the fracture population. The en échelon arrangements above deep-seated shear zones indicate dextral slip on WNW to NW, and sinistral slip on NNE to ENE faults, conformable with earthquake data. 2) During the polyphase tectonic, the six sets led to basin and horst formation, block compartmentalisation, rotation, horsetail splay, rhomb-graben in relay zone of strike-slips, and volcanism. 3) Listric faults are absent and the steeply-dipping faults are antithetic, synthetic, or form extensional flower structures above $4 \mathrm{~km}$ depth. The Plio-pleistocene/present syn-sedimentary deformation caused a deep half graben in the Eyjafjarðaráll Basin (Ey), fault growth, rollover, and sediment onlaps, with some of the faults still active. 4) The plate boundaries of K-R/Ey, GOR/Öxarfjörður/NRZ, and DL delimit a major microplate labelled here as Grímsey-Tjörnes-Dalvík. 5) The WNW earthquake cluster in GOR corresponds either to a blind horsetail splay fault 
or to initiation of a transform segment parallel to the HFF. The described tectonic-sedimentary-magmatic deformation is relevant to other diverging plate boundaries where similar sets control the hydrocarbon and geothermal resources.

\section{Keywords}

Kolbeinsey Ridge, Iceland Northern Rift Zone, Tjörnes Transform Zone, Grímsey Oblique Rift, Grímsey-Tjörnes-Dalvík Microplate, Magmatic/Sedimentary/Tectonic Processes

\section{Introduction}

Diverging plate boundaries consist of both rift and transform segments [1] [2], regardless of whether they are above a hotspot or not. Spreading is accommodated by stretching across the rift and by shear motion along the transform zones. Classically, rifts/ridges are identified by regular magnetic anomalies, e.g. [3], and normal fault-controlled basins with hydrocarbon accumulation. The axial rifts/ridges are also a locus of tectonically emplaced calderas, e.g., [4] [5] [6], and geothermal resources, e.g., [7], where a single rift episode consists of dyke injection and related earthquakes [8] [9]. Transform zones, on the other hand, are primarily identified by earthquakes and shear motions, e.g., [10]. However, the deformation becomes complex with time, and develops features such as diverse ridge geometry and failed rift segments [11], instability in rift and transform zones [12] [13] [14] [15] [16], anomalous magnetic chrons due to rift relocation, e.g., [17], or varied degree of rift obliquity [18]. Due to their impacts on basin formation, petroleum system development, volcanism and hydrothermal fluid circulation, these boundaries have been studied in continental and ocean crusts of various ages, offshore as onshore.

Iceland is a window into the tectonic evolution of diverging plate boundaries that span in age from upper Tertiary to present, and in extent from land to shelf. Decades of intensive instrumental monitoring increased the understanding of active rifting, transform faulting, magma injection and crustal deformation. Studies of older structures, at a regional scale as well as offshore, have received less attention comparatively, thus leaving gaps in the literature. The present tectonic analysis contributes towards filling such a gap in an area of $16,500 \mathrm{~km}^{2}$ covering several rift, ridge, oblique rift and transform segments as well as a microplate (Figure 1). This paper presents:

- A comprehensive and continuous regional tectonic map of the Kolbeinsey Ridge (KR), Northern Rift Zone (NRZ), the Tjörnes Fracture Zone (TFZ), and a major microplate obtained from aerial images, bathymetric and topographic maps.

- An overview of the styles of deformation and further insights into the tectonic configuration of the plate boundaries and the microplate. 


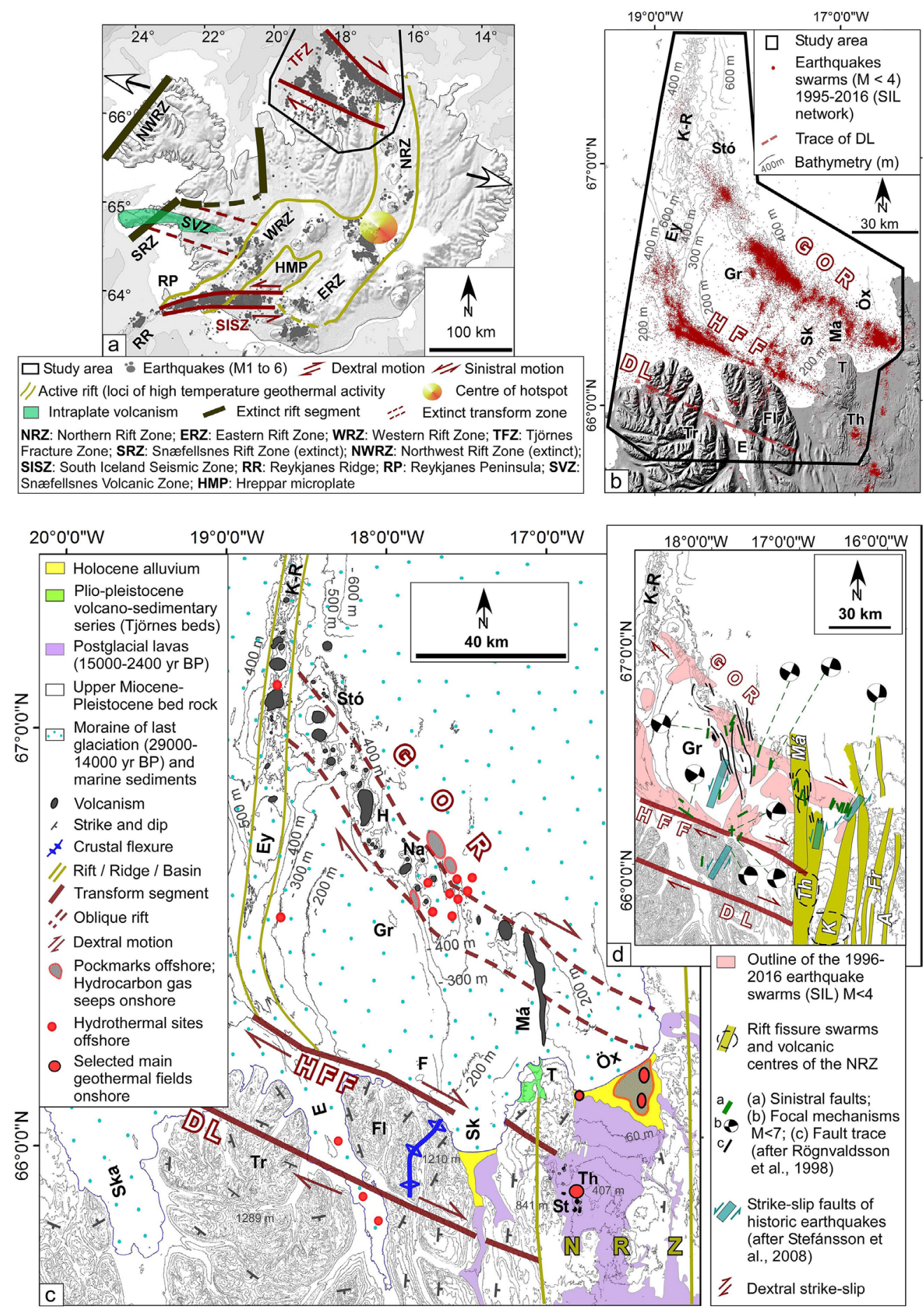

Figure 1. (a) Diverging plate boundaries, intraplate tectonic, and earthquakes in Iceland; (b) The study area in North Iceland and the earthquake swarms within the TFZ; (c) Main geological elements spanning upper Miocene-present; (d) The rift fissure swarms of the Northern Rift Zone, the three segments of the Tjörnes Fracture Zone, and focal mechanisms of selected earthquakes. Abbreviations on Figures (b) to (d) are, K-R: Kolbeinsey Ridge; Má: Mánáreyjar; Th: Theistareykir; K: Krafla; Fr: Fremrinámar; A: Askja; GOR: Grímsey Oblique Rift; HFF: Húsavík-Flatey Fault; DL: Dalvík Lineament; Stó: Stóragrunn; H: Hóllinn; Na: Nafir; Gr: Grímsey; E: Eyjafjarðaráll; Ska: Skagafjörður; Tr: Tröllaskagi; E: Eyjafjörður; Fl: Flateyjarskagi; F: Flatey; Sk: Skjálfandi; T: Tjörnes; Öx: Öxarfjörður; St: Stórihver. On Figure (c), the sub-marine hydrothermal sites of Eyjafjörður are after [152] [153], the K-R and GOR after [150] [151]. Pockmarks offshore are after [118], and hydrocarbon gas seeps onshore after [154]. Geothermal field in Öxafjörður is after [148], and in Theistareykir after [149]. 
- Correlation of the observed tectonics with selected surface and depth data and their interpretation for a better understanding of the deformation.

Not only are the results of this multidisciplinary structural analysis relevant to the geology of Iceland and other rift and transform zones, but they also provide a knowledge base for exploration of geothermal or hydrocarbon resources in the context of diverging plate boundaries in general.

\section{Geological Settings}

\subsection{Diverging Plate Boundaries at Large}

As rifting, transform faulting and oblique rifting are all present in the study area, the recall of common complexities associated with these boundaries is necessary as a structural frame.

1) Rifting, transform faulting, and their instabilities are known to occur in both young and old oceanic ridges and in continental rifts. One of the complexities at these boundaries is when spreading is accommodated by a set of propagating and receding rift segments, leading to a " $\mathrm{V}$ " shape geometry of magnetic anomalies and pseudofaults on the flanks of the spreading centres [19] [20] [21] [22].

2) In bookshelf tectonic [23] between overlapping rift segments [24] [25] [26] [27], or within transform zones, e.g., [16] [28] [29], conjugate dextral and sinistral strike-slips faults accommodate the rotation [30] [31]. However, regional block rotations between plate boundaries, e.g., [32], whether banking the spreading centres, e.g., [33], across transform zones, e.g., [34], or along rift axis, e.g., [35], would cause sinuosity and bend in the tectonic/magmatic structures [4] [36] [37] [38] [39].

3) Oblique rifting occurs [13] [40]-[45]) when the relative plate motion is not parallel to the directions of the principal strain, e.g., [46] [47], and the plates spread obliquely compared to the ridge/rift trend [18]. Rift obliquity can be moderate $\left(15^{\circ}-45^{\circ}\right)$ [48] to high $\left(45^{\circ}-75^{\circ}\right)$ [49], but extension is accommodated by both the normal and the strike-slip faults [18], and characterised by en échelon segments that are surface expression of deeper structures [41] [48]-[53]. Oblique rifts are considered to initiate above reactivated non-aligned major crustal weaknesses [34] [50] [54] [55] [56] [57], where strain is localised [58] [59], and magmatism is present at depth [60] [61]. Such rifts can evolve with or without transform/transfer segments [42] [43] [62] [63] [64]. The migrating deformation due to increased rift obliquity not only leads to gradual curvature of rift/ridge axis and their internal en échelon segments [37] [48] [61], but also to stress field rotation/re-orientation/permutation in polyphase tectonics [65] [66] [67].

4) Fracturing with extensional faults and conjugate strike-slips is intense in areas under the influence of rift/transform or oblique rifting [26] [38] [57] [68]-[75]. The en échelon segmentation and fracture sinuosity are typical fracture geometries above deeper shear faults, and even along individual 
strike-slip faults [18] [39] [42] [43] [48] [51] [76] [77] [78] [79] [80]. The relay zones of normal faults in rifts, e.g. [81] or the stepovers between en échelon strike-slip segments in transform zones [28] [51] are some of the other complexities. The stepovers could evolve into pull-apart basin (strike-slip regime) or rhomb-graben (transtension or oblique extension) [4] [29] [34] [37] [74] [82] [83], and asymmetric basins can be bounded by normal faults on one side and parallel strike-slip faults on the other side in weak transform zones subject to oblique-slips [34] [50] [54]. These structures are among the most prolific for hydrocarbon and geothermal exploration. In addition, the partitioning of the damage zones of strike-slips faults [52] [57] [84] [85] control the fluid flow and permeability along individual structures.

\subsection{Iceland and Its Northern Shelf}

Above a hotspot [86] [87], Iceland is linked to the Tertiary North Atlantic Igneous Province that is the second magmatic phase since the opening of North Atlantic about 62 - $58 \mathrm{Ma}$ [88] [89]. The oldest igneous series in Iceland are 16 - 15 $\mathrm{Ma}$ [90], but the island has been in the making since $24 \mathrm{Ma}$ [41] or $26 \mathrm{Ma}$ [91] [92] when the active rift jumped westwards from Aegir to the K-R and propagated onshore with a complex tectonic history.

Presently, the American and Eurasian Plates separate along the plate boundaries in Iceland and on its shelf (Figures 1 (a)-(d)) at a rate of $2 \mathrm{~cm} / \mathrm{yr}$ in the direction $\mathrm{N} 105^{\circ} \mathrm{E}$ [93]. The active rifts are the K-R and NRZ, the Eastern Rift Zone (ERZ), and the Western Rift Zone (WRZ), also called Reykjanes-Langjökull Rift Zone. The transform zones are the TFZ, and the South Iceland Seismic Zone between the WRZ, ERZ and south of the Hreppar Microplate. Oblique rifting occurs along the GOR [77], the Reykjanes Peninsula [53] [94] and the Reykjanes Ridge [42] [95] [96] with typical en échelon segmentation [78] [79] [97], V-shape geometry [98] and pseudofaults [21] [99].

Rift segments comprise fissure swarms of normal faults, open fractures and eruptive dykes, as well as calderas, acidic rocks [100] [101] and high temperature geothermal fields [102]. Transform zones are loci of earthquakes [2] [103] [104] [105], continuous seismicity [106], and shear motions [107] [108]. Intraplate volcanism [109] [110] and earthquakes [111] occur outside active plate boundaries. Past rift jumps [69] [112] [113] led to several extinct rifts that stretch presently from central Iceland towards the northwest [69] [114], and to abandoned Tertiary transform segment [69] [115] [116]. The main geological elements of study area are as follows (Figures 1(b)-(d) and Figure 2(a)):

1) The K-R is a narrow ridge, while the NRZ is $70 \mathrm{~km}$ wide, up to $200 \mathrm{~km}$ long with several fissure swarms. Only the westernmost swarm of the NRZ (Theistareykir-Mánáreyjar) falls within the study area. The TFZ is $20 \mathrm{~km}$ long and $70 \mathrm{~km}$ wide, and comprises three NW-WNW striking segments, i.e., the GOR, the Húsavík-Flatey Fault (HFF) and the Dalvík Lineament (DL). The accumulated dextral motion of the TFZ since upper Tertiary is $100 \mathrm{~km}$ [101] 

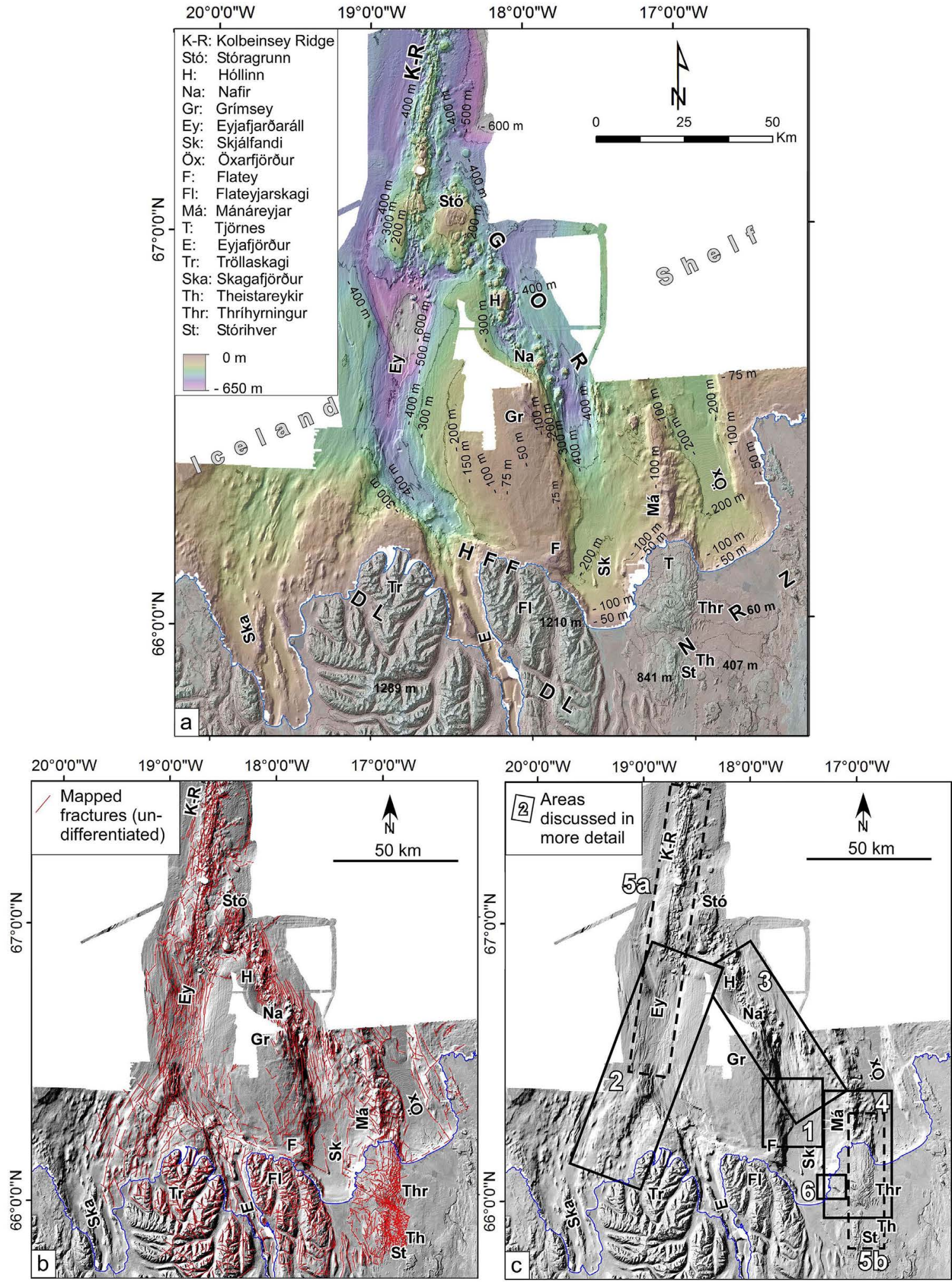

Figure 2. The study area. (a) Combined Multibeam, Single beam and Spot 5 images superimposed on Digital Elevation Model (DEM) as the basis for the structural interpretation. The Multibeam bathymetric data are from [77] [186] [187], the Single beam from Icelandic Coast Guard (Sjómælingar), and the DEM (ISNET 93) from National Land Survey of Iceland (Landmælingar Íslands); (b) Distribution of the mapped structures in the study area; (c) Location of six selected areas for more detailed analysis of the deformation. Abbreviations for tectonic structures same as for Figure 1. 
or $140 \mathrm{~km} \mathrm{[117],} \mathrm{and} \mathrm{the} \mathrm{subsidence} \mathrm{in} \mathrm{the} \mathrm{order} \mathrm{of} \mathrm{hundreds} \mathrm{of} \mathrm{metres.} \mathrm{The}$ offshore basins are Öxarfjörður, Skjálfandi, Eyjafjarðaráll, Eyjafjörður and Skagafjörður. The HFF cuts the Theistareykir Fissure Swarm, e.g., [101], stretches offshore [119] [120] and intersects the Skjálfandi and Eyjafjarðaráll Basins. The Holocene marine volcanic edifices align on the K-R, and in the four en échelon segments of GOR, namely Stóragrunn, Hóllinn, Nafir and Mánáreyjar, indicating dextral motion across this oblique rift, e.g., [77] [118]. Except a small ridge in Skjálfandi [119], the main highs are Grímsey and Mánáreyjar offshore, and Tjörnes, Flateyjarskagi and Tröllaskagi on land. The Grímsey High is caught between the HFF, GOR and the Eyjafjarðaráll Basin. Although the kinematics of this high is poorly known, it has been speculated that the Grímsey High is a microplate as it is caught between these plate boundary segments [16].

2) Onshore, the Miocene crust is $15 \mathrm{Ma}$ in North Iceland and at least $10 \mathrm{Ma}$ in the study area [121], but offshore, magnetic anomalies show an undisturbed spreading along the K-R for the past 11 - $20 \mathrm{Ma}$, e.g., [122]. The landward continuation of this ridge is the Skagi paleo-rift (predecessor to NRZ), active at about $12 \mathrm{Ma}$ [117] [123]. Opinions diverge on whether this paleo-rift jumped eastward to the NRZ around 6/7 Ma [117] and the TFZ initiated then [101], or the NRZ became active at $8-8.5 \mathrm{Ma}$ [124] and the TFZ at $9 \mathrm{Ma}$ [117]. Regardless of timing, the plate boundary reorganisations caused uplift and subsidence, unconformities, flexuring, major block rotation [125], and intense fracturing [71] [115] [126] in the study area.

3) The Miocene - present series consist of basaltic lavas, hyaloclastites, acidic rocks, and local sediments [127] onshore. The igneous crust is covered unconformably by a $1-\mathrm{km}$ thick Plio-Pleistocene sequence including the fossil rich marine Tjörnes beds and intercalated lignite, alternating lavas, thin glacial tillites and fluvio-lacustrine sediments [128] [129]. The Tertiary-Pliocene accumulations fill the offshore basins up to a thickness of $4 \mathrm{~km}$ [130] [131] [132] [133] [134]. They are covered by the 29,000 - 14,000 yr BP moraines from the last glaciations [135], and by younger marine sediments. Older series are deformed at depth [133], while chirp and backscatter data suggest that the youngest rifting episodes are mostly between 12,000 and $3000 \mathrm{yr} \mathrm{BP}$ [136] [137].

4) About $2 / 3$ of the present transform motion across the TFZ is accommodated by GOR and $1 / 3$ by the HFF [138] [139]. Micro-seismicity is continuous along the HFF, GOR, and occasionally on individual faults (Figure 1(b) and Figure 1(d)), with earthquakes reaching M6 to M7 [16] [140] [141] [142]. The focal mechanisms show dextral strike-slip on the WNW/NW and sinistral strike-slip on NNE/NE Riedel shears in the TFZ [108] [141] [143], with an occasional oblique-slip component. Earthquakes are also linked to magma injection within rift segments such as the 1976 Kópasker earthquakes [107]), triggered by dyke injections along the Krafla Fissure Swarm, e.g., [144], and 
the 2014 eruption in Bárðarbunga [145] [146]. Magmatism also occurs on strike-slip faults of the transform zone such as the $2400 \mathrm{yr}$ BP eruption along a WNW blind shear fault in Theistareykir [147].

5) The main high temperature fields of the study area (Figure 1(c)) are in Öxarfjörður on land, e.g., [148], as well as in Theistareykir [149]. Geothermal activity offshore was observed during dredging locally at K-R as well as to the west and east of Grímsey, and hydrothermal vents have also been discovered in a few places [150] [151] [152] [153]. Pockmarks are known offshore in GOR [118], and onshore to the north of the Krafla and Theistareykir fissure swarms where hydrocarbon gases emanate [134] [154] [155]. The gases likely originated from marine sediments and lignite [156] [157] and maturated by the high geothermal gradient in Skjálfandi $\left(110^{\circ} \mathrm{C} / \mathrm{km}\right)$ and Öxarfjörður $\left(200^{\circ} \mathrm{C} / \mathrm{km}\right)$ Basins [158].

6) Most of the recent structural mappings, however, focused on the N-S extensional fractures [127] [159] [160] and eruptive dykes [127] of the rift/ridge [118] [159] [161] [162]. The Riedel shears were identified locally offshore, e.g., [163] and particularly the WNW and NW sets have been mapped in places onshore [71] [101] [164]. Geothermal manifestations are considered to be fracture-controlled [165] [166]. Their detailed tectonic settings, however, are overall poorly known, except in Theistareykir where a multidisciplinary tectonic investigation demonstrated that six sets of extensional and shear fractures belonging to the rift and transform zones control this resource [167] [168] [169].

\section{Data and Method}

The mapped upper Tertiary-present structures are fractures (faults, open fractures, prominent joints), and volcanic edifices. Considering the size of the area and the challenges in identifying the structures, a combination of several processed Multibeam/Single beam bathymetric maps, Digital Elevation Model (DEM), and Spot 5 satellite photos (natural, black and white, infrared channels) (Figures 2(a)-(c)) was used to detect the regional tectonic structures. As fracture identification relies on light and shadow on images, a structure may be easily detected or not at all, or its trace could appear differently on various image types. The variety of images used enhanced the chances of fracture identification. All images were reported as single layers in GIS, having true North and no distortion. The structures were handpicked and drawn directly in GIS where the range of image resolutions allowed observations down to metre-scale.

To provide an overview of the deformation in time and space, the multidisciplinary tectonic analysis is organised in this paper as follows:

- The comprehensive regional structural pattern of the rifts, transform zone and oblique rift is presented on new regional tectonic maps with a continuous coverage (Figure 3(a)).

- Features such as the fracture sets, trace, length, geometry, and motions are described (Figure 4), and the frequency of each set calculated in an overall 
statistical analysis. Some fractures are mildly curved, in which case their strikes were defined as a straight line between the two end-points of the fracture traces. Furthermore, up to $5 \%$ of the mapped fractures may not be of tectonic origin, but such a small fraction does not skew the overall frequency of the fracture sets in the statistical analysis.

- Six areas that reflect best the variety of tectonic structures at and between rift, transform and oblique rift segments are selected on the overall tectonic map to describe in detail the styles of deformation (Figure 2(c) and Figures 5-10).

- The extensional and shear fractures (Figure 3(a)) are interpreted in terms of the main highs, basins and volcanism (Figure 11), along with their implications for plate boundaries and a microplate (Figures 12(a)-(e)). The interpreted topographic, Multibeam/Single beam bathymetric cross-sections, as well as the seismic reflection profiles show the extent of the identified deformation from the surface down to greater crustal depths (Figures 13(a)-(g)). The correlation of the deformation and the earthquakes reflects the relation of the active deformation and the underlying major structures, with hints on fault reactivation (Figures 14(a)-(d)).

- The main conclusions (Figures 15(a)-(k)) and some discussions summarise the contribution of this paper.

\section{Observations}

\subsection{The Structural Pattern}

About 2258 fracture segments were identified on the images, representing a total length of $8069 \mathrm{~km}$ (Figure 3(a)). The fractures cut the volcanic-sedimentary series of the upper Miocene (10 - 3.3 Ma), Plio-Pleistocene (3.3 - $0.8 \mathrm{Ma})$, upper Pleistocene-Holocene (0.8 Ma-present) and the postglacial lavas (15,000 - 2400 yr BP) onshore, but offshore they displace the postglacial formations on the seafloor. The marine Holocene volcanism are large edifices, seamounts and plateaux, while the Pleistocene - late Holocene eruptive craters onland are much smaller in size. The main features of the structures on the map are as follows:

1) As fractures are at various stages of evolution since the upper Tertiary, they have more or less strong traces in the topography. Their traces are generally stronger (sharp) in the older bedrock as faults accumulated slips, leading to a more differentiated topography. The younger Holocene faults and open fractures have subtler traces. Fractures are generally segmented along total length (Figure 3(a)) as they have not yet coalesced into single major faults.

2) Segments of an individual fault can present opposite dip directions because faults (and dykes) in Iceland are generally steeply-dipping in the range of $75^{\circ}$ to $85^{\circ}$ [72] [73]. The HFF is one of the best examples as segments of this WNW fault to the west of Flatey offshore dip towards the northwest, but dip towards southwest between Flatey and Theistareykir onshore (Figure 3(a) and Figure 4(a)). 


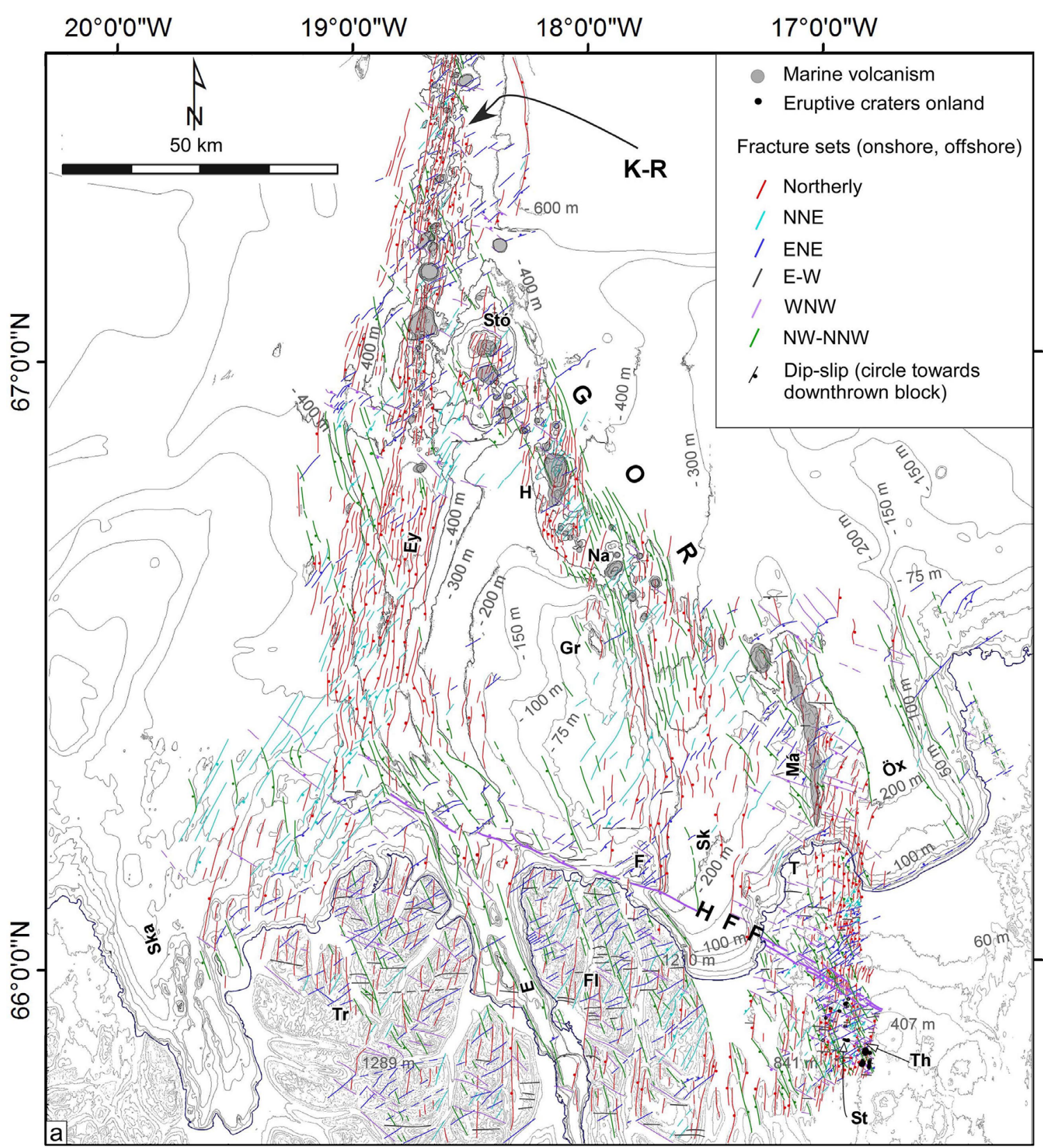

\begin{tabular}{|c|c|c|c|}
\hline \multirow{8}{*}{$\begin{array}{l}\text { Fracture sets onshore-offshore } \\
\text { North Iceland } \\
\begin{array}{l}\mathrm{N}=8069 \mathrm{~km} \\
\left(\mathrm{~N} 0^{\circ}-20^{\circ} \mathrm{E}\right)\end{array}\end{array}$} & Strike & Total length (km) & $\%$ of total population \\
\hline & $\begin{array}{l}\text { Northerly } \\
\left(\mathrm{NO}^{\circ}-20^{\circ} \mathrm{E}\right)\end{array}$ & 3152 & 39,1 \\
\hline & $\begin{array}{c}\text { NNE } \\
\left(\text { (N21 }-30^{\circ} \mathrm{E}\right)\end{array}$ & 914 & 11,3 \\
\hline & $\begin{array}{c}\text { ENE } \\
\left(51^{\circ}-77^{\circ} \mathrm{E}\right)\end{array}$ & 1260 & 15,6 \\
\hline & $\begin{array}{c}\text { EW } \\
\left(\mathrm{N} 90^{\circ}-99^{\circ} \mathrm{E}\right)\end{array}$ & 260 & 3,2 \\
\hline & $\begin{array}{c}\text { WNW } \\
\left.\text { (N108 }{ }^{\circ}-135^{\circ} \mathrm{E}\right) \\
\end{array}$ & 765 & 9,4 \\
\hline & $\begin{array}{c}\text { NW/NNW } \\
\left.\text { (N145 }-\mathrm{N} 170^{\circ} \mathrm{E}\right) \\
\end{array}$ & 1718 & 21,2 \\
\hline & Sum & 8069 & 100 \\
\hline
\end{tabular}

Figure 3. Interpreted tectonic pattern in rift, transform, and oblique rift offshore and onshore North Iceland. (a) The six fracture sets, presented in different colours; (b) The statistical analysis of the observed fractures showing the frequency of each fracture set (rose diagram) and their percentage in the total fracture population (table). 

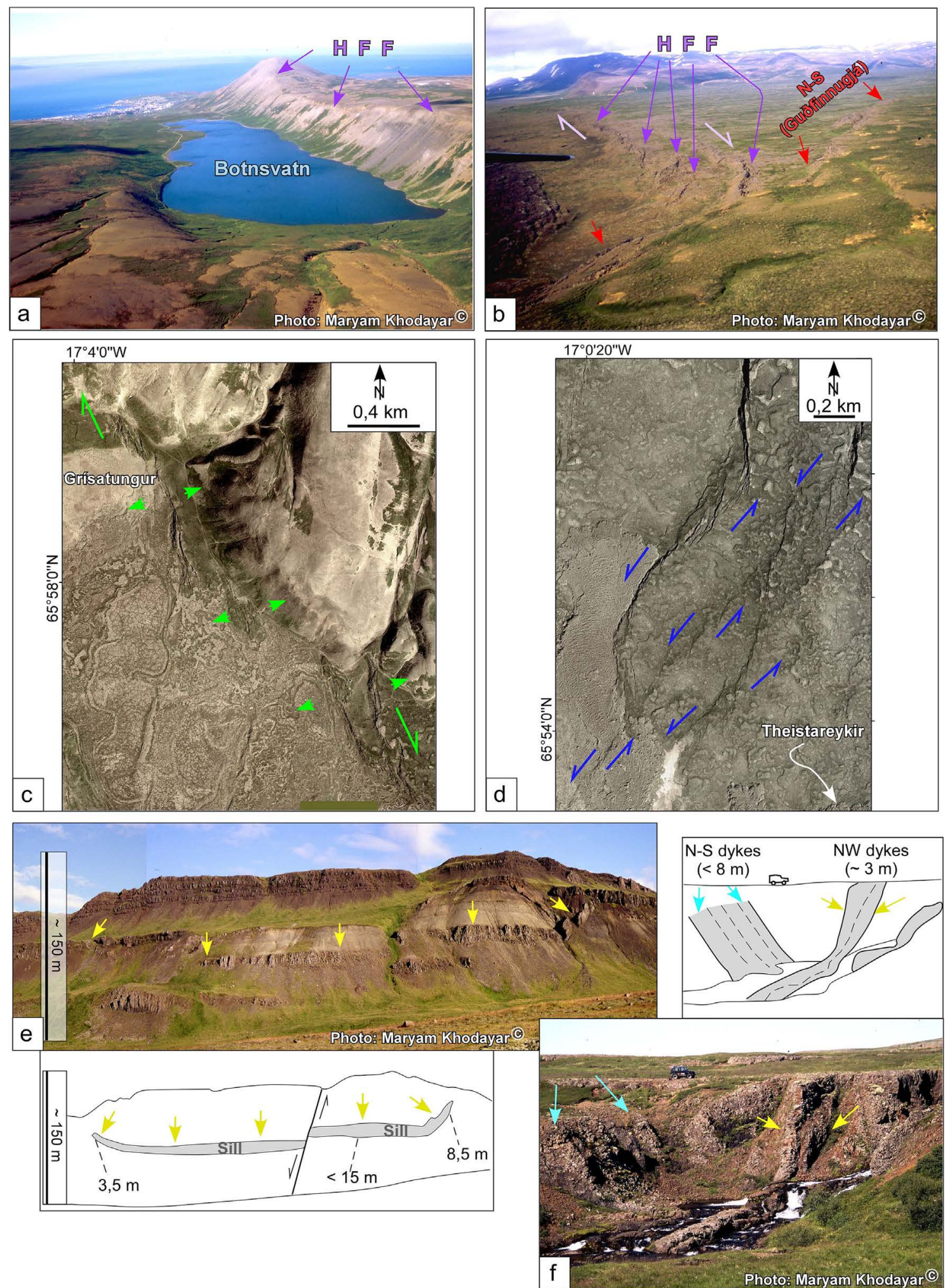

Figure 4. (a) The main WNW transform segments of the HFF in the upper Tertiary outcrops to the north of Botnsvatn Lake; (b) The younger left-stepping en échelon segments of the HFF in the postglacial lavas, intersecting the N-S normal faults of Guðfinnugjá; (c) and (d) Spot 5 images showing the en échelon arrangements of open fractures, respectively, along NW dextral and ENE sinistral faults (modified from [169]); (e) and (f) Respectively, a saucer-shape sill (modified from [176]), and multiple dyke injection (Khodayar, unpublished data), in the $1-\mathrm{km}$ and $1.5 \mathrm{~km}$ eroded crust of West Iceland (see text for explanation). 


\section{Area 1}
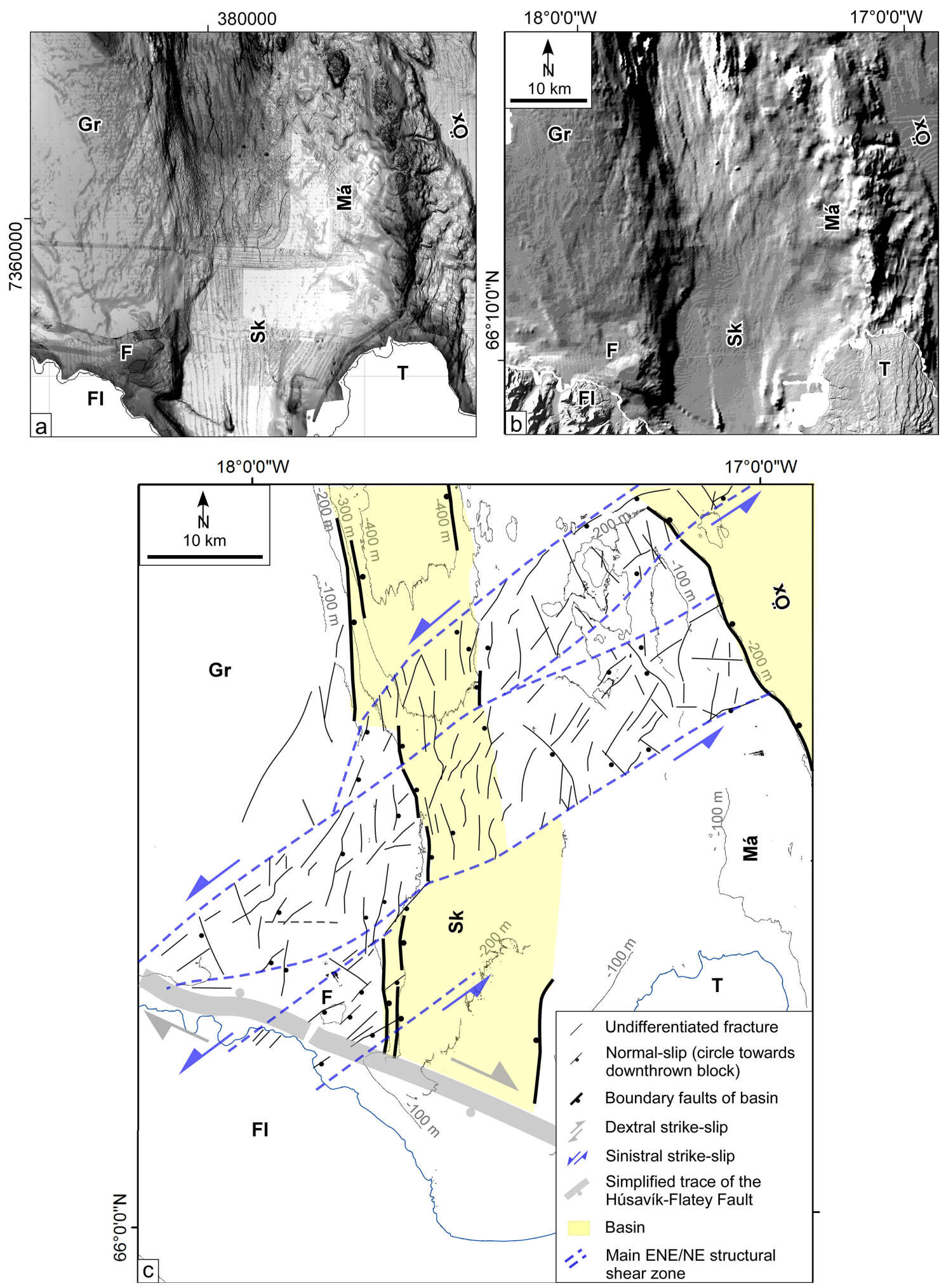

Figure 5. The main ENE shear zones of Area 1 offshore. (a) and (b) Different processing of Single beam images, presented in UTM and ISNET 93, respectively, showing that the same structure can appear differently on images; (c) The ENE sinistral shear zones cutting Skjálfandi, Mánáreyjar and Öxarfjörður, identified based on the right-stepping en échelon arrangement of short NNE segments and sinuosity of N-S and NNE segments along these zones. 


\section{Area 2}
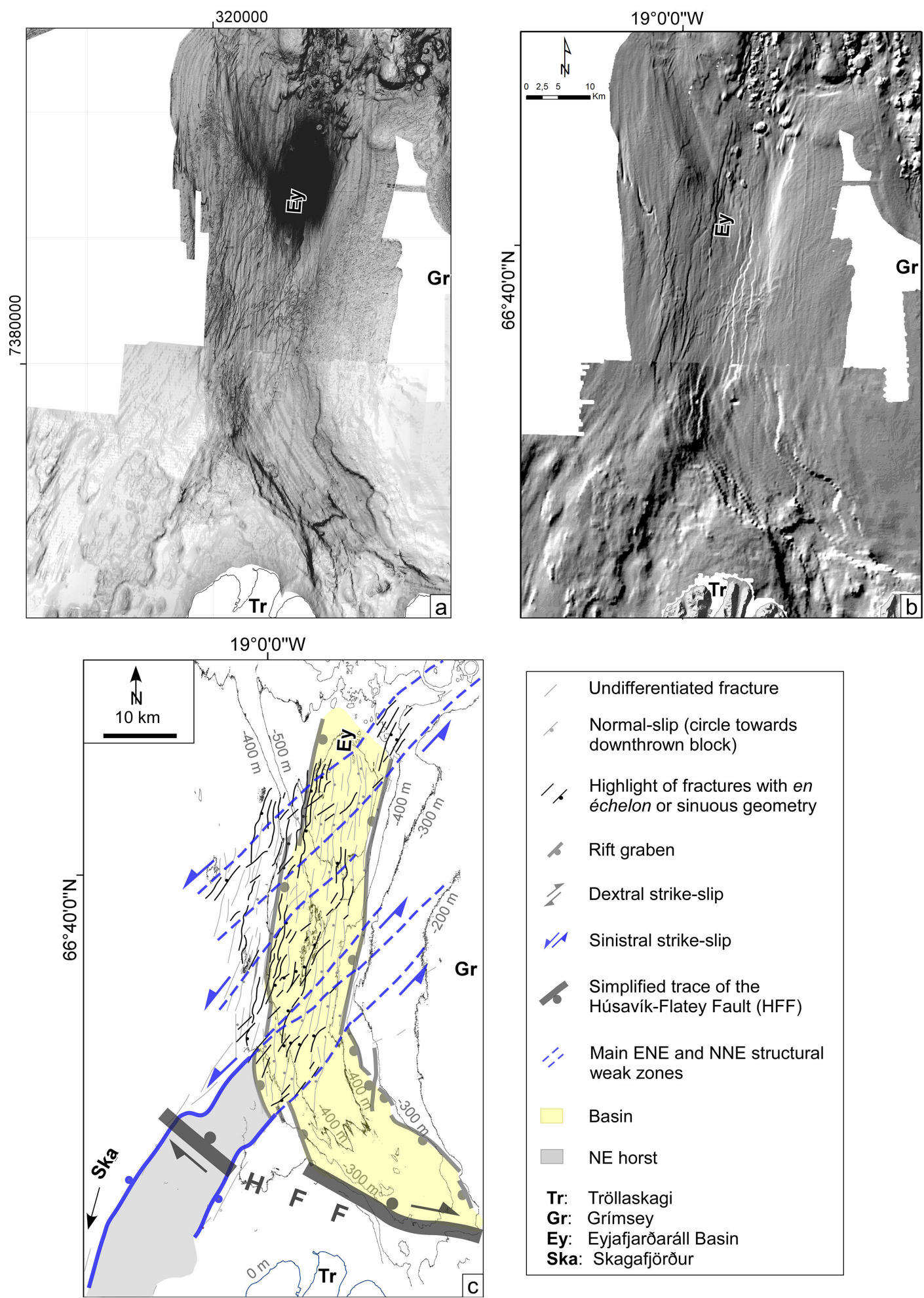

Figure 6. The main NE/ENE shear zones of Area 2 offshore. (a) and (b) Different processing of Single beam images, presented in UTM and ISNET 93, respectively; (c) The NE/ENE sinistral shear zones cutting the Eyjafjarðaráll Basin, identified based on the right-stepping en échelon arrangement of the short NNE segments and sinuosity of the N-S and NNE segments. The southernmost shear zone is in the continuation of the NE horst to the north of Skagafjörður-Tröllaskagi. To the south of the Eyjafjarðaráll Basin, the NNE faults dip to the northwest within two of the shear zones. 


\section{Area 3}
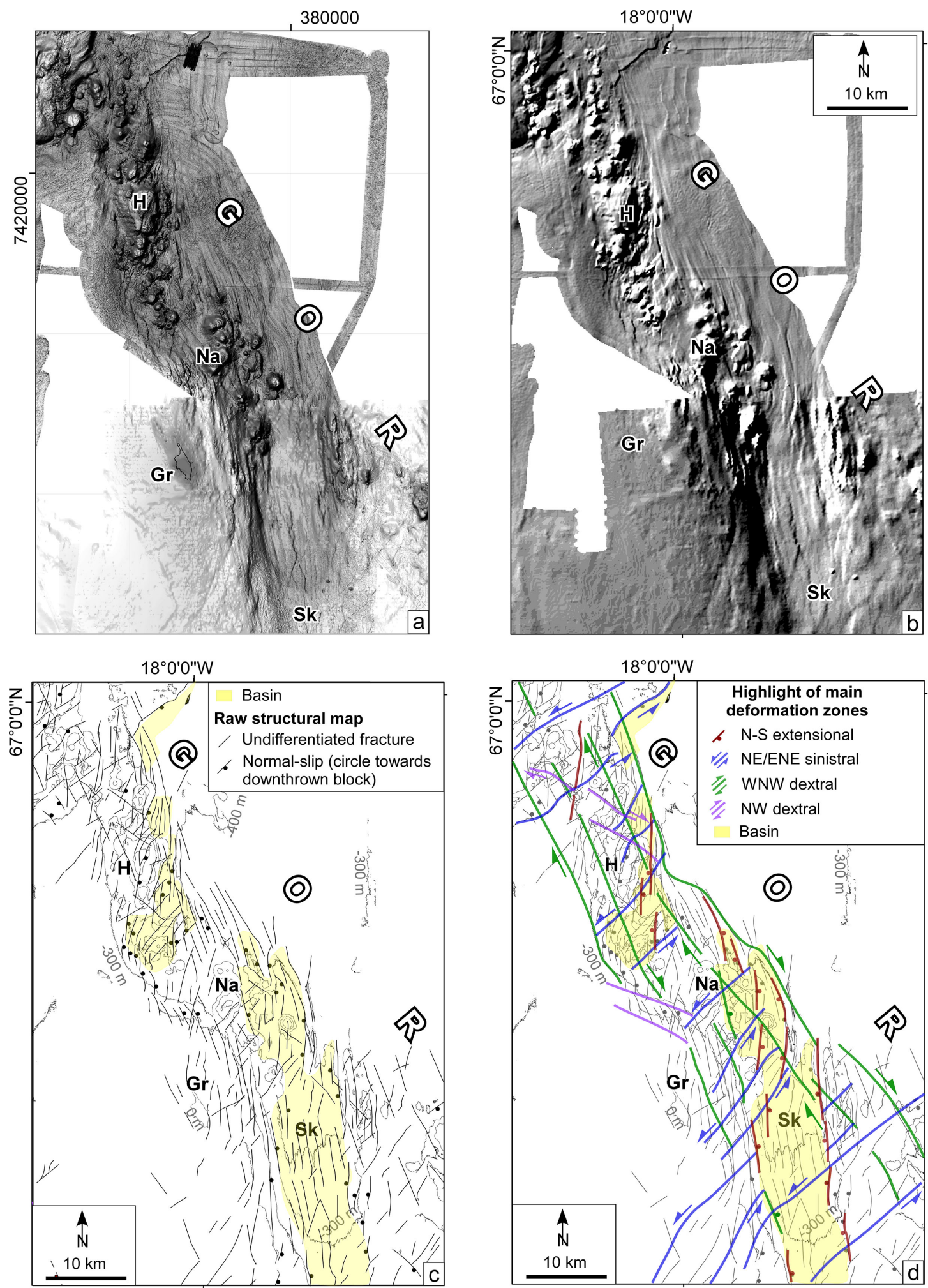

Figure 7. The main shear zones of Area 3 offshore. (a) and (b) Multibeam/Single beam images presented in UTM and ISNET 93, respectively; (c) The N-S normal as well as the NNE/ENE sinistral and the WNW/NW dextral shear faults with sinuous and en échelon arrangements form horsts and grabens within the NW-trending GOR; (d) Interpretation of the main normal and shear zones in GOR. 


\section{Area 4}

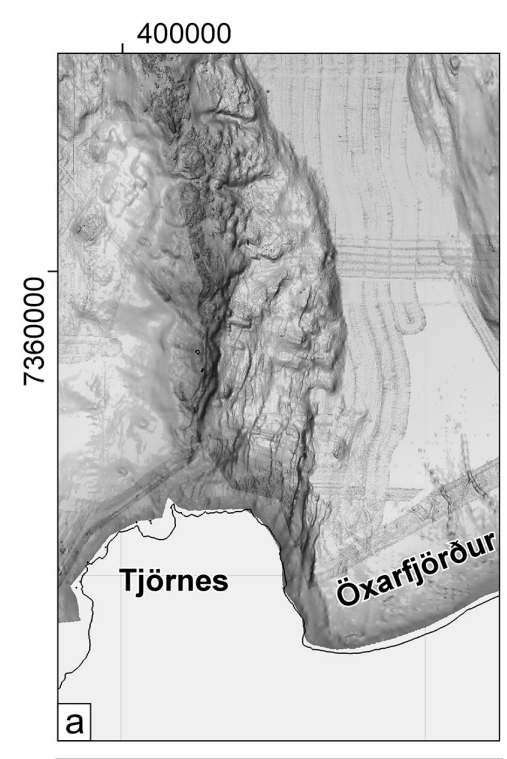

\begin{tabular}{|ll|}
\hline \multicolumn{2}{|c|}{ Common abbreviations } \\
Öx: & Öxarfjörður \\
Má: & Mánáreyjar \\
Sk: & Skjálfandi \\
T: & Tjörnes \\
F: & Flatey \\
Fl: & Flateyjarskagi \\
Thr: & Thríhyrningur \\
Th: & Theistareykir \\
HFF: & Húsavík-Flatey Fault \\
\hline
\end{tabular}
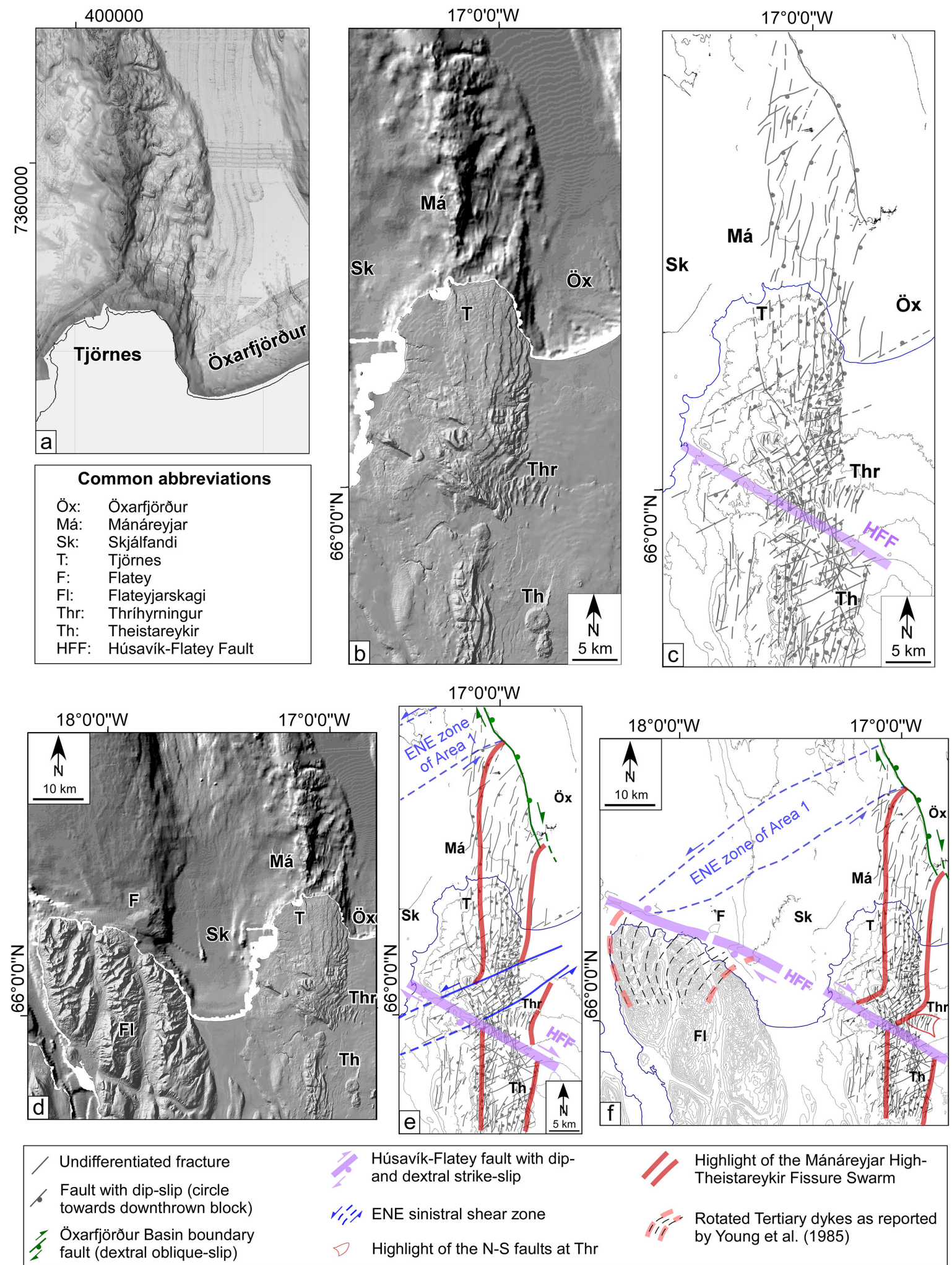
Highlight of the Mánáreyjar High-
Theistareykir Fissure Swarm

11 Rotated Tertiary dykes as reported by Young et al. (1985)

Figure 8. Area 4 offshore and onshore. (a) and (b) Single beam images offshore, respectively, in UTM and ISNET 93, along with Spot 5 and DEM onshore; (c) Interpretation of the faults shown on Figure (b); (d) The same image types covering a wider structural frame for the interpretation; (e) and (f) Two alternatives for the change in the fault strike from N-S to ENE. 


\section{Area 5}
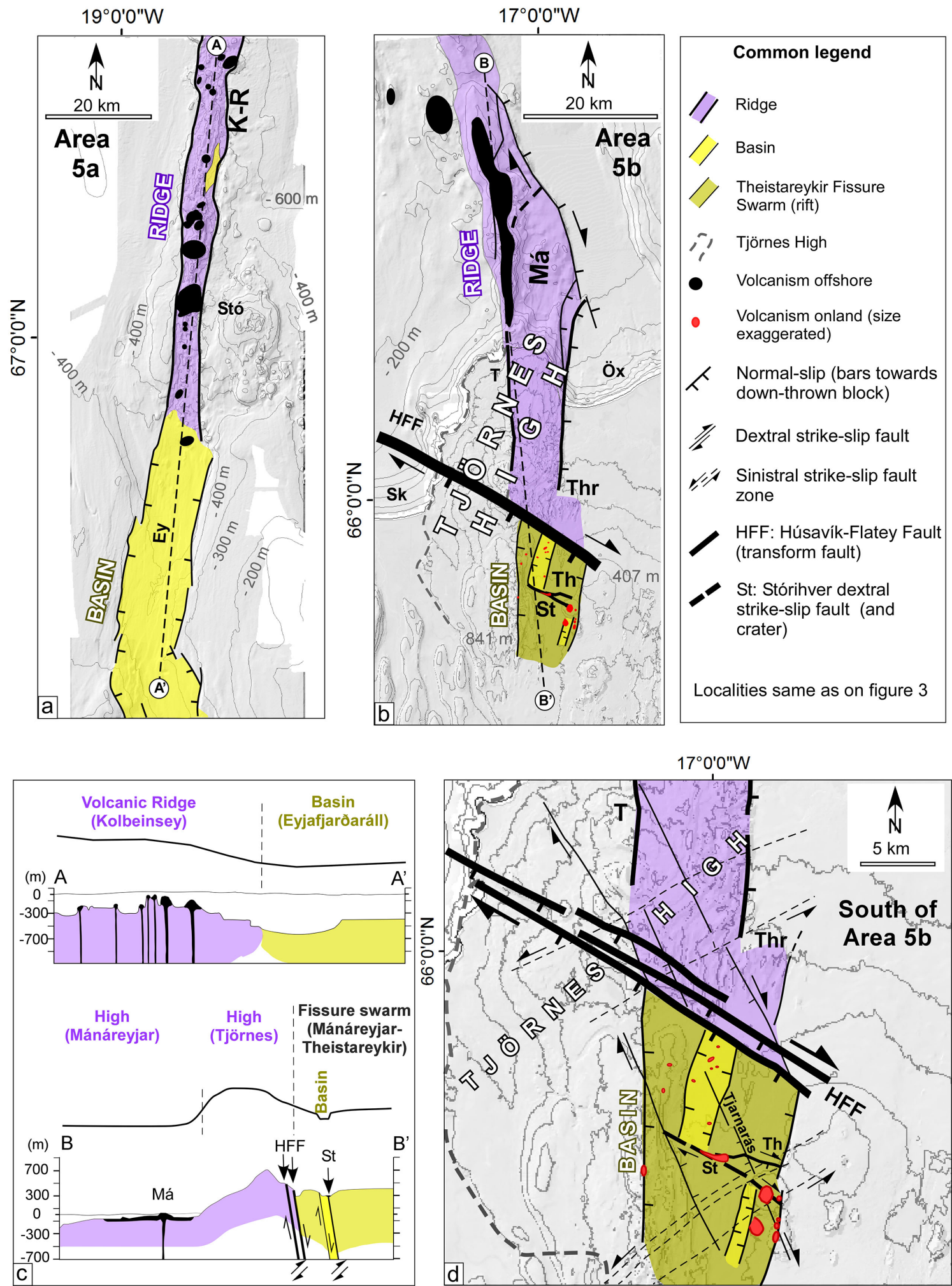

Figure 9. Along-axis "Ridge to Basin" configuration of the rift structures in Area 5. (a) and (b) Maps showing that the N-S ridges pass into basin along axes, and that the volcanism is mostly on the ridges and lesser within the basins; (c) Cross-sections along the axes of the N-S ridges and basins; (d) Closer look at the small N-S grabens, and the main WNW, NW and ENE faults in Theistareykir (see text for explanation). 


\section{Area 6}
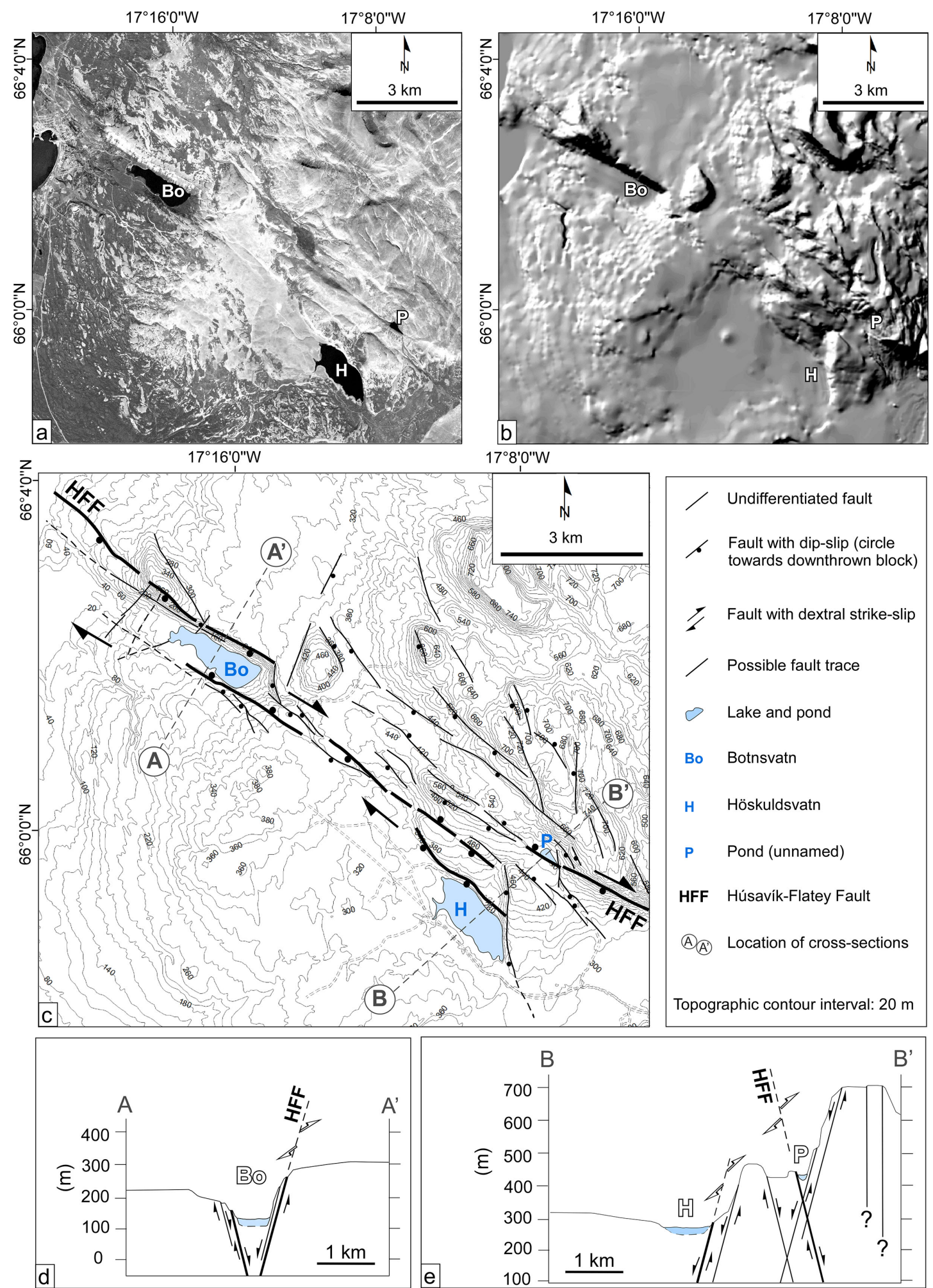

Figure 10. Some deformation associated with the HFF in Area 6 onshore. (a) and (b) Respectively, Spot 5 and DEM showing the HFF, the surrounding faults, and a few water bodies; (c) The deformation along the left-stepping en échelon oblique-slip segments of the HFF, the rhomb-grabens occupied by lakes, and the NW horsetail splays; (d) and (e) Cross-sections showing the tectonic configuration of the rhomb-grabens and the water bodies. 


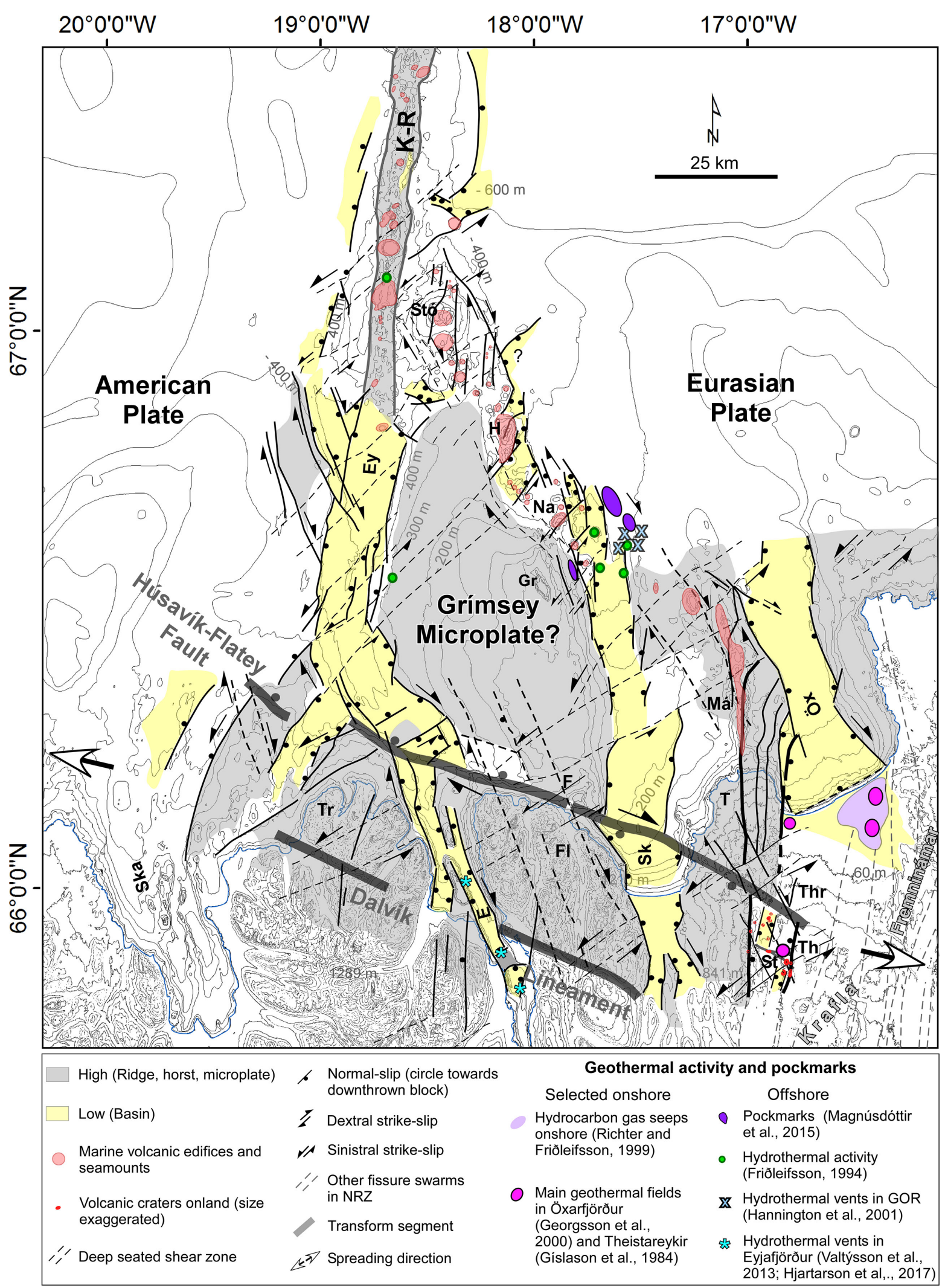

Figure 11. The interpreted tectonic map of the structures at and between plate boundaries offshore and onshore. The simplified map shows the main highs, basins, shear zones, volcanism, hydrothermal sites and pockmarks offshore, as well as the main geothermal fields and hydrocarbon seeps onshore. 


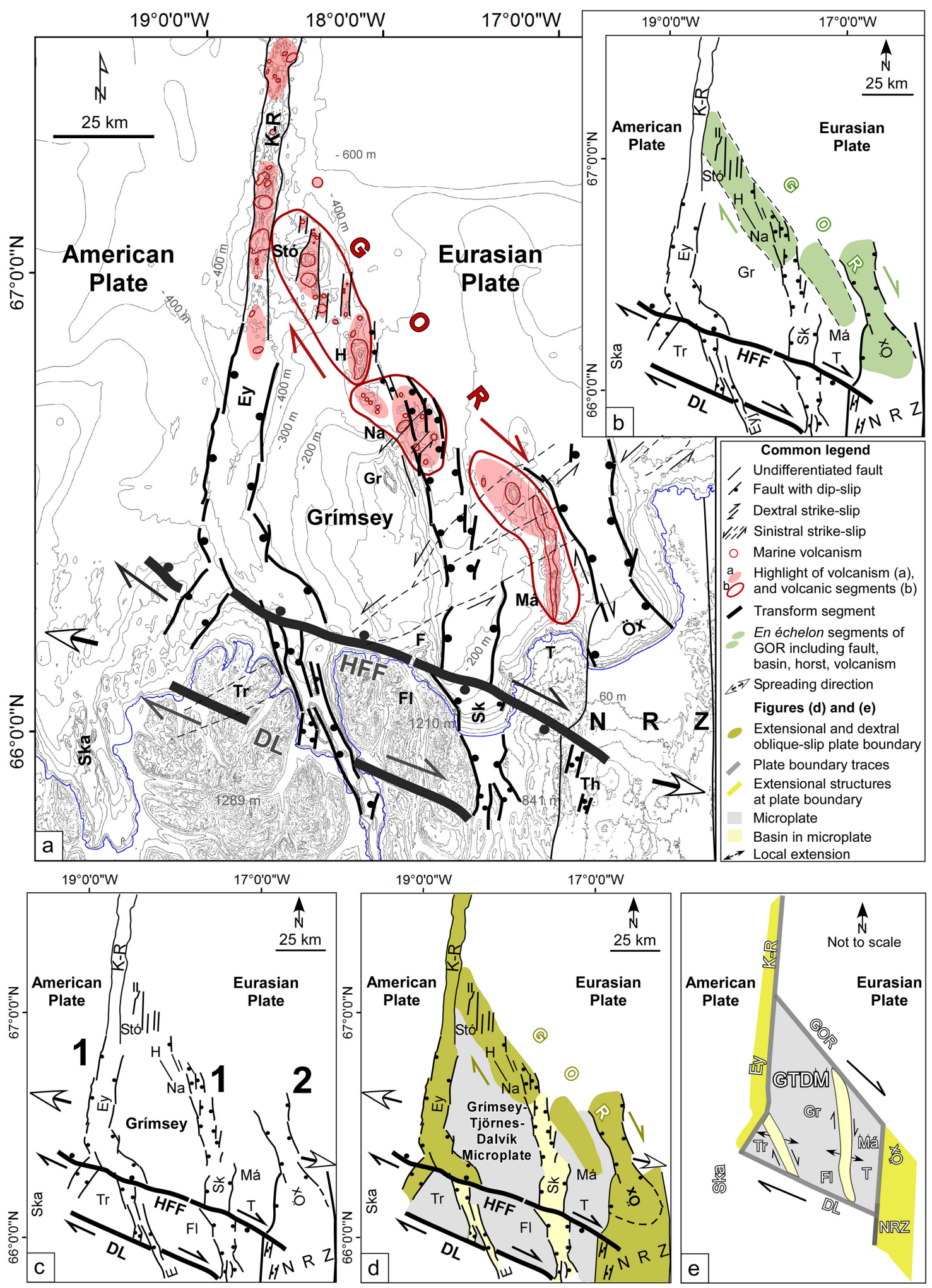

Figure 12. Interpretation of the regional structures in terms of plate boundaries and a microplate. (a) Distribution of volcanism in the K-R, and in the NW en échelon segments of GOR from Stóragrunn to Mánáeyjar; (b) The Öxarfjörður Basin as a likely structure of GOR; (c) The structures to the west and east of Grímsey along which the plates separate; (d) The structures at the plate boundaries, the Grímsey-Tjörnes-Dalvík major microplate, as well as the Skjálfandi and Eyjafjörður intra-microplate basins; (e) The rhomb-shaped microplate bounded by plate boundaries. 

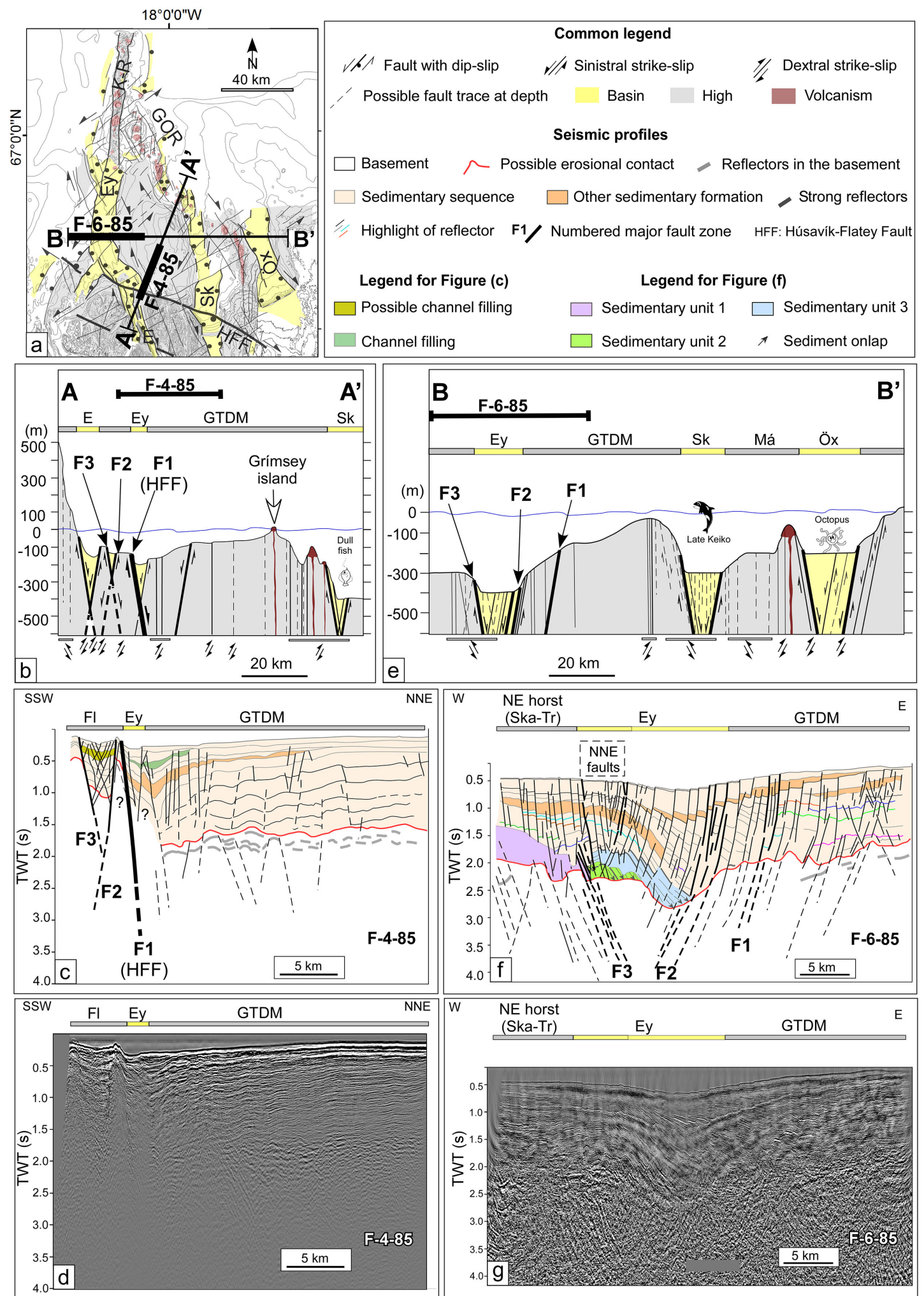

Figure 13. Interpretation of the structures at depth. (a) Location of the topographic/bathymetric cross-sections and $2 \mathrm{D}$ vintage seismic reflection profiles; (b) The morphostructures along cross-section A-A'; (c) and (d) The interpreted and raw seismic profile F-4-85; (e) The morphostructures along cross-section B-B'; (f) and (g) Interpretation and raw seismic profile F-6-85. Vertical scales exaggerated on all sections to show the details. On interpreted sections A-A' and B-B', the thick lines are the fault traces of Figure 13(a), and the thin dashed lines the detailed fracture segments of Figure 3(a). 

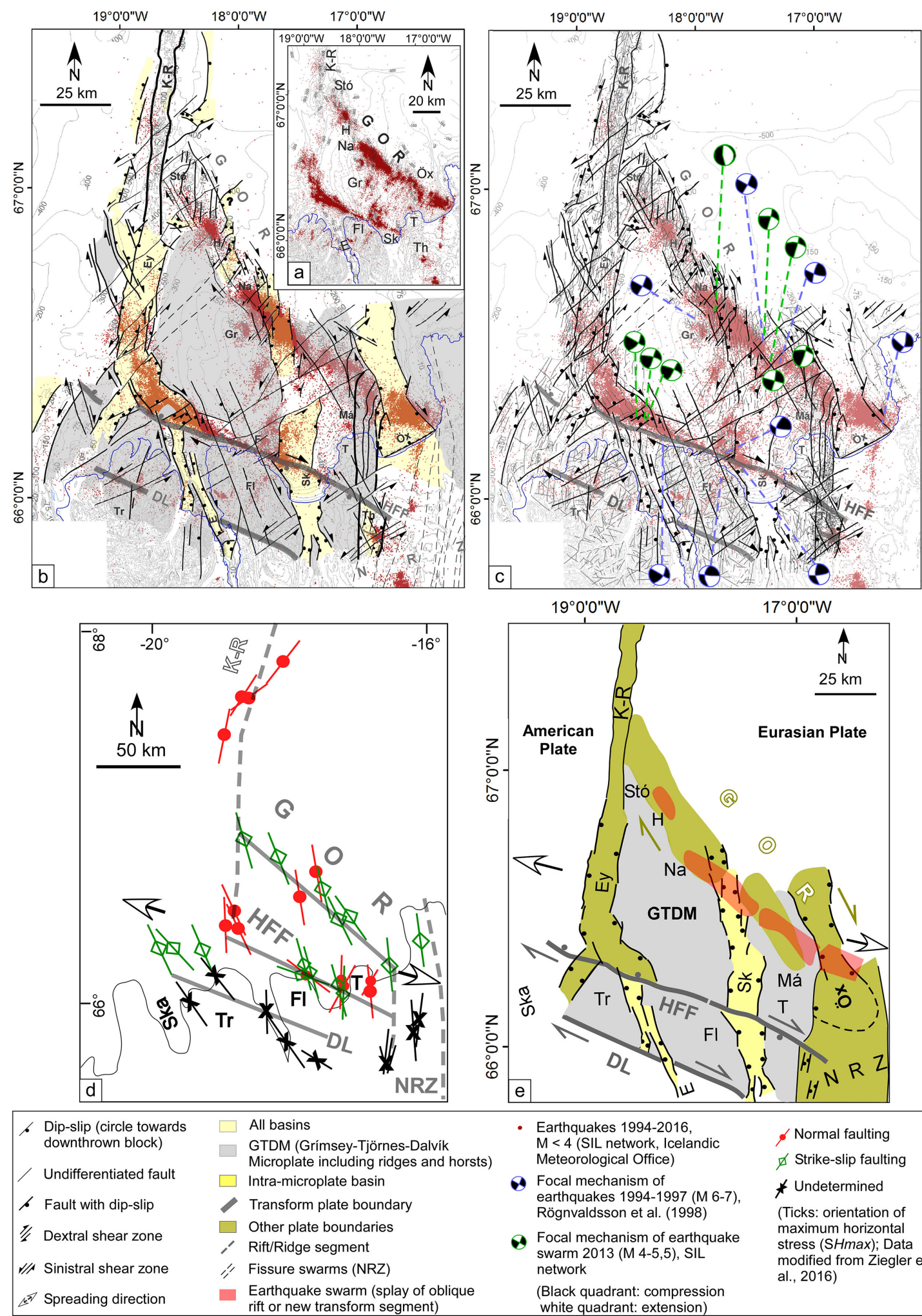

- Earthquakes 1994-2016, $\mathrm{M}<4$ (SIL network, Icelandic Meteorological Office)

- Focal mechanism of earthquakes 1994-1997 (M 6-7), Rögnvaldsson et al. (1998)

Focal mechanism of earthquake swarm 2013 (M 4-5,5), SIL network

(Black quadrant: compression Normal faulting $\not$ Strike-slip faulting * Undetermined

(Ticks: orientation of maximum horizontal stress (SHmax); Data modified from Ziegler et al., 2016)

Figure 14. Correlation of present-day earthquakes and underlying upper Tertiary-present structures. (a) Raw map of 1995-2016 earthquake swarms (SIL network); (b) Seismic lineations in the earthquake swarms and the mapped structures; (c) Selected focal mechanisms of earthquakes; (d) The stress map of North Iceland (modified from [184]), showing complex normal and strike-slip fault regimes; (e) The earthquake swarms of GOR may correspond either to a blind splay of GOR, or to initiation of a transform segment parallel to the HFF and DL. 

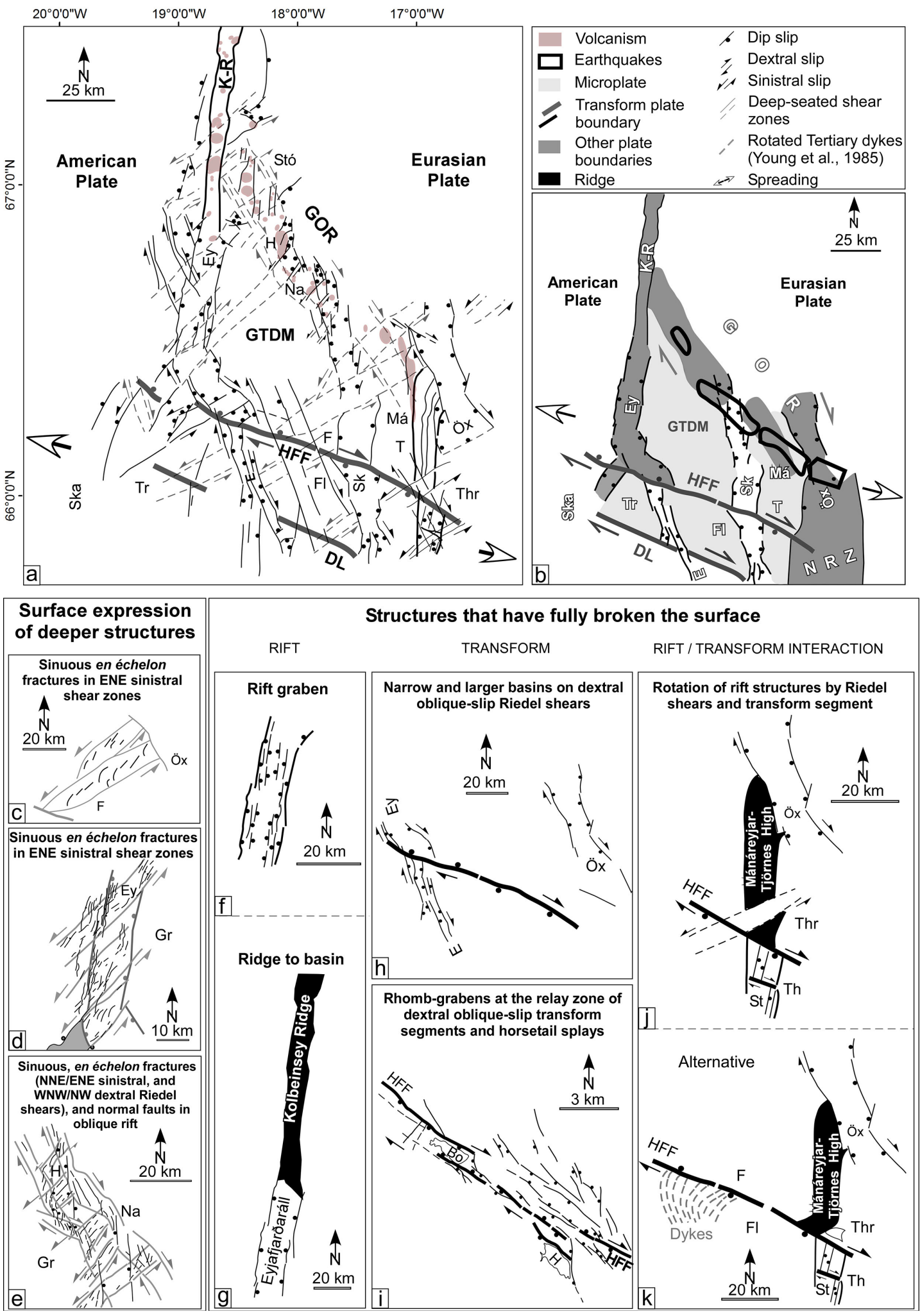

Figure 15. Summary of the regional tectonic structures and the styles of deformation. (a) Simplified tectonic map of the main basins, highs and shear zones at the rift, transform and oblique rift segments offshore/onshore North Iceland; (b) The plate boundaries, the major GTD Microplate, two intra-microplate basins, and the earthquakes in GOR above a possible blind WNW structure; (c) to (e) Surface expression of deeper shear structures; (f) to (k) The range of deformation associated with the extensional and shear fractures that have fully broken the surface (see text for explanation). 
3) The statistical analysis of the fractures shows the existence of six sets striking N-S, NNE, ENE, E-W, WNW and NW (Figure 3(b)). Individual NW segments are the longest, reaching up to $30 \mathrm{~km}$ such as the western boundary fault of the Öxarfjörður Basin (Figure 3(a)), followed by single N-S fault segments with a maximum length of $20 \mathrm{~km}$. Single NNE and ENE fractures are the shortest, with a length of up to $2 \mathrm{~km}$ at most.

4) All fractures display dip-slip, with values ranging from $1 \mathrm{~m}$ to several hundreds of metres onshore, and between $<10$ and $100 \mathrm{~m}$ on the seafloor, except in GOR where the dip-slip reaches locally up to $200 \mathrm{~m}$. Particularly in the upper Tertiary crust, the fractures with strongest traces are also those with the highest dip-slip (Figure 4(a) and Figure 4(b)). The segmented N-S faults $\left(\mathrm{N} 175^{\circ}\right.$ to $\left.\mathrm{N} 20^{\circ} \mathrm{E}\right)$ are purely extensional, without coherent en échelon arrangements. For the lack of marker horizons, the en échelon geometry and fracture sinuosity were used as criteria to identify the shear motions. The WNW $\left(\mathrm{N}_{108^{\circ}}-\mathrm{N} 135^{\circ} \mathrm{E}\right)$ and NW $\left(\mathrm{N} 145^{\circ}-\mathrm{N} 170^{\circ} \mathrm{E}\right)$ segments display systematic left-stepping en échelon arrays typical of dextral strike-slip motion, while the ENE $\left(\mathrm{N} 51^{\circ}-\mathrm{N} 77^{\circ} \mathrm{E}\right)$ and $\mathrm{NNE}\left(\mathrm{N} 21^{\circ}-\mathrm{N} 30^{\circ} \mathrm{E}\right)$ segments have a right-stepping arrangement indicative of sinistral strike-slip motion (Figures 4(b)-(d)). These shear fractures are, however, often oblique-slip due to their combined strike- and dip-slips. No criterion determined satisfactorily the

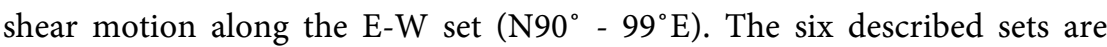
clearly a combination of fractures resulting from rifting and transform faulting, which was first identified in Theistareykir in a recent structural analysis [169].

5) Similar to Theistareykir [169], the fracture population reflects here the presence of several deep-seated structural zones, expressed at the surface either as areas of higher fracture density, and/or concentration of fractures with en échelon geometry.

6) The N-S faults of the rift are the single most frequent structures with $39 \%$ of the fracture population (Figure 3(b)), but the Riedel shears of the transform zone and the oblique rift represent $61 \%$. Among the Riedel shears, the NW set is the most frequent (21\%), and the E-W set the least (3\%). The E-W, NW and N-S sets are the deepest structures, as interpreted from resistivity anomalies [169] [170].

\subsection{Styles of Deformation}

The study area has some $2000 \mathrm{~m}$ elevation difference between land and seafloor as the highest peak is $1289 \mathrm{~m}$ in Tröllaskagi onshore and the deepest part of the seafloor is about - $650 \mathrm{~m}$ in the Eyjafjarðaráll Basin (Figure 2(a)). Six areas are selected (Figure $2(c)$ ) to show in detail the styles and variety of tectonic deformation, most of which are reported for the first time by this study.

\subsubsection{Area 1}

Area 1 is offshore and covers a great portion of the Grímsey High and the 
Skjálfandi Basin, as well as the totality of the Mánáreyjar High (Figure 5(a) and Figure 5(b)). A series of ENE, NNE, NW and N-S fractures fall within three parallel ENE zones that cross the Skjálfandi Basin diagonally and stretch into the south of the Grímsey High (Figure 5(c)). In these ENE zones, fractures of the four sets have more subtle traces with far less apparent dip-slips than the NW and N-S boundary faults of the Öxarfjörður and Skjálfandi Basins. The ENE and NNE/NE segments are organised in typical right-stepping en échelon arrays compatible with a sinistral strike-slip motion across the ENE zones (Figure $5(c)$ ). The sinuosity of the N-S, NNE and NW short fractures within the two northernmost ENE zones is compatible with fault drag across the sinistral ENE zones. The traces, geometry and comparatively small dip-slips $(<50 \mathrm{~m})$ of these short segments indicate that the fractures are at a younger stage of development, acting very likely as surface expression of deep-seated ENE strike-slip shear zones.

\subsubsection{Area 2}

Area 2 in the Eyjafjarðaráll Basin displays similar deformation to Area 1 (Figures 6(a)-(c)). The Eyjafjarðaráll Basin strikes N-S over 2/3 of its length but turns to WNW at the approach of the HFF where it is bounded by faults of the same strike (Figure 2(a), Figure 3(a) and Figure 6(c)). In the N-S portion of the basin, shorter NNE and ENE segments are organised in right-stepping en échelon arrays. They are distributed in three possible parallel NE/ENE zones, each with $<5 \mathrm{~km}$ width. At the approach of the boundaries of these ENE zones, a few of the short N-S, NE, ENE and NNE segments display gentle sinuosity, reflecting fault drags by the sinistral strike-slip motion of the ENE zones.

The southernmost NE/ENE zone in particular hosts remarkable deformation where some of the N-S faults of Eyjafjarðaráll are rather NNE (Figure 6(c)). These NNE faults have dip-slips, and have been interpreted as rift-parallel normal faults in the literature. However, they all dip towards north-northwest, which excludes their role as the boundary faults of the basin. These short segments are the surface expression of deep-seated sinistral strike-slip structure(s) crossing the basin. Furthermore, the southernmost NE zone is in exact continuation of a horst to the north of Skagafjörður-Tröllaskagi. The Eyjafjarðaráll Basin changes its strike from N-S to WNW precisely after intersecting this NE shear zone.

\subsubsection{Area 3}

Area 3 shows the complexity of tectonic along the GOR, part of its flanks, and the Skjálfandi Basin (Figures 7(a)-(d)). From north of Hóllinn to the north of Skjálfandi, the fracture pattern is dominated by a high number of short NW striking faults, in the presence of N-S, NNE, and a few WNW segments. All fracture sets have dip-slips, and the left- and right-stepping en échelon arrangements indicate dextral motion on NW and WNW fractures, and sinistral motion on NNE to ENE segments (Figure $7(c)$ ). The NW, ENE, and N-S oblique-slip 
faults control a few local basins in Nafir and Hóllinn, along with volcanism.

The concentration of high fracture density, en échelon segments, and fracture sinuosity indicate that the deformation is partitioned in several extensional and shear zones in the GOR (Figure 7(d)). Most of the mapped fractures fall within two parallel NW deformation bands with dextral strike-slip characters, which are located towards the outer edges of the GOR, while the remaining mapped structures coincide with shorter NNE-ENE sinistral, WNW dextral and N-S extensional zones inside this oblique rift. These configurations indicate that extension at this plate boundary is accommodated by the overall dextral motion along the NW striking GOR as well as by smaller ENE sinistral, WNW dextral, and $\mathrm{N}-\mathrm{S}$ extensional zones.

\subsubsection{Area 4}

Area 4 extends from Mánáreyjar offshore to Tjörnes and Flateyjarskagi onshore, and displays relevant features related to the rift (Figures 8(a)-(c)) and its interaction with the transform zone (Figures $8(d)-(f)$ ). Three aspects are analysed in these relations. First is the series of N-S normal faults stretching from Mánáreyjar to the Theistareykir Fissure Swarm. No major N-S fault is identified in the western half of the Tjörnes High and the mapped N-S faults occupy the eastern halves of the Mánáreyjar and the Tjörnes Highs. Judging from the displacement of the seafloor and the topography, a great majority of these faults are eastward dipping with dip-slips in the range of $<10$ and to $100 \mathrm{~m}$. As the faults dip to the east, they exclude a typical horst structure for these two highs. Instead, the N-S faults form the western flank of the Theistareykir/Öxarfjörður Basin (Figures 8(b)-(d)). Secondly, a portion of the offshore faults on the Mánáreyjar High and southeast of it bends from N-S to NNE at the approach of the Öxarfjörður Basin. These systematic bends are typical fault drags induced by the dextral strike-slip motion on the NW-striking western boundary fault of the Öxarfjörður Basin (Figure 8(b)-(c) and Figure 8(e)). Thirdly, a zone of tightly parallel ENE faults crosses the N-S normal faults to the north of the HFF on the Tjörnes High (Figure 8(d)). The majority of these ENE faults have pronounced trace and dips to the southeast, with apparent dip-slips up to $100 \mathrm{~m}$. Towards the west of this ENE zone, a few short ENE segments display a mild right-stepping en échelon arrangement typical of sinistral motion. At Thríhyrningur to the east, however, the ENE zone isolates a small wedge composed of N-S faults, which dip mainly eastwards. Although the ENE fractures are widespread and form a separate set in the adjacent Theistareykir area to the south [167] [168] [169], the described deformation here is rather specific. Two explanatory alternatives are suggested:

1) Either the ENE zone is an independent sinistral shear zone cutting diagonally across the N-S normal faults of Tjörnes. In this case, the N-S faults of Thríhyrningur are a portion of the Mánáreyjar-Theistareykir N-S structures, detached by and dragged along the ENE sinistral zone (Figure 8(e)).

2) Or, the ENE faults were originally a part of the N-S faults of Mánárey- 
jar-Theistareykir, which rotated clockwise to ENE on Tjörnes north of the HFF (Figure 8(f)). Likewise, on Flateyjarskagi to the south of the HFF, a high number of Tertiary dykes are also known to have rotated clockwise [125]. The clockwise rotation of those dykes on one side of the HFF, and of the faults on the other side are regional fault drags compatible with the dextral motion of this transform segment. In both alternatives, the N-S faults of Thríhyrningur would remain coherently a small detached wedge, caught between the ENE sinistral zone and the HFF dextral fault. As dykes feed the lavas in which they are found [171], and the lavas are Miocene in age here, the dyke rotation likely dates from an early stage of transform development. On the other hand, the fault rotation is, or has lasted, at least until Quaternary, i.e., the age of the youngest rocks cut by the described N-S faults.

\subsubsection{Area 5}

Area 5 presents interesting features related to the N-S regional structures of the K-R (Area 5a), Mánáreyjar, Tjörnes and Theistareykir (Area 5b) (Figures 9(a)-(d)). Two points should be noted prior to the analysis. Mánáreyjar High strikes overall N-S but its northern part is rather NW within the GOR. The total length of each ridge and basin can be slightly greater than shown on the maps.

The K-R and the Mánáreyjar Highs are pierced by volcanic edifices, but each of these highs evolves into a N-S basin to the south. This configuration is labelled here as "along-axis Ridge to Basin" (Figures 9(a) and Figure 9(b)). In the case of the K-R and the Eyjafjarðaráll Basin, the proportion of ridge to basin is balanced as the K-R is about $70 \mathrm{~km}$ long and Eyjafjarðaráll $65 \mathrm{~km}$ on map. An along-axis cross-section shows that the K-R is some $400 \mathrm{~m}$ higher in altitude than the shallowest part of the Eyjafjarðaráll Basin, but $600 \mathrm{~m}$ higher than the deepest part of that basin. The volcanism is concentrated on the K-R High and not in the subsided basin.

Similarly, the Mánáreyjar and Tjörnes Highs evolve along-axis into the Theistareykir low to the south of the HFF. Although the western part of Theistareykir is topographically a high (flank), the structure is overall equivalent to a basin as most of it is subsided. Additionally, it contains two narrow N-S basins with a 2.7 and $0.7 \mathrm{~km}$ width, cutting the postglacial and the $2400 \mathrm{yr}$ BP lavas (Figures 9(b) and Figure 9(d)). Despite the general configuration "Ridge to Basin" here, there are a few differences compared to the K-R/Eyjafjarðaráll. First, the proportion of ridge to basin is uneven as the ridge/high is $\sim 90 \mathrm{~km}$ long and the basin $\sim 25 \mathrm{~km}$. Secondly, the elevation is overall a mirror image of the K-R/Eyjafjarðaráll. While the top of the Tjörnes High is $400 \mathrm{~m}$ above the surface of the N-S basins in Theistareykir, the top of the Mánáreyjar High is $400 \mathrm{~m}$ lower than those basins (Figure 9(c)). Thirdly, the volcanic edifices are concentrated mostly on the Mánáreyjar High, but smaller eruptive craters exist also in the "basin" part in Theistareykir. A closer look at the structures in Theistareykir reflects interesting structural controls of some geological processes. For example, the last eruption of $2400 \mathrm{yr}$ BP occurred on the Stórihver Fault (StF), which is a WNW blind dex- 
tral strike-slip fault of the transform zone and is perpendicular to this N-S rift fissure swarm [147]. Additionally, the geothermal activity is controlled by the N-S rift-parallel faults, but more dominantly by the Riedel shears of the transform zone [168] [169]. These are the NW and WNW dextral oblique-slip faults (e.g., the Tjarnarás Fault and the horsetail splay of the StF), as wells as the ENE and NNE deep-seated sinistral strike-slip faults (Figure 9(d)). All of these sets are equally widespread in the present study area.

\subsubsection{Area 6}

Area 6 displays some detailed deformation along a $16 \mathrm{~km}$ length of the HFF onshore. It is emphasised that Spot 5 (Figure 10(a)) and DEM images (Figure 10(b)) provide a different view and depth to the observations, and the structural interpretation (Figure 10(c)) takes into account the average strikes and fault geometry seen on both image types. Also, only the structures relevant to the discussions are selected from the original map (Figure 3(a)) to be shown here (Figure 10(c)).

Three features exhibit the main styles of deformation. First, the HFF consists of several WNW segments, most of which dip to the southwest (Figure 10(c)). A few NW, N-S and NNE segments are also present. All fractures have dip-slip, while the left-stepping en échelon segmentation indicates dextral motion along the HFF and other WNW and NW faults. Secondly, the NW faults are a separate and widespread set. Locally, however, WNW and NW segments can act as horsetail splay of each other, as along the HFF here and in the Theistareykir area [169] [172].

Thirdly, there are three water bodies (Botnsvatn, Höskuldsvatn and an unnamed pond), which are $<50 \mathrm{~m}$ deep (Figures 10(a)-(e)). To the west, two WNW segments of the HFF dip towards each other and form a 1-km wide graben occupied by Botnsvatn. The main transform segment is to the north, dips southwest, and has $\geq 200 \mathrm{~m}$ dip-slip (Figure 4(a) and Figure 10(c)), while the southern segment dips to the northeast with $\leq 40 \mathrm{~m}$ apparent dip-slip (Figure 10(d)). A small hill, controlled by a NW fault dipping to the southwest, bounds the graben to the east. From there the graben structure decreases in width to 200 $\mathrm{m}$ and dies out shortly. Farther east, the elevation drops regionally about $400 \mathrm{~m}$ from north of the small pond towards Höskuldsvatn through a series of WNW and NW horsts and grabens (Figure 10(e)). Two of these WNW segments form a very narrow graben where the small pond is pinched in. Similar to Botnsvatn, the Höskuldsvatn is flanked to the north by a southwest dipping segment of the HFF with $\leq 20 \mathrm{~m}$ dip-slip, and to the east by a NW fault, dipping to the west. The Botnsvatn and the Höskuldsvatn are shallow lakes with likely flat bottoms, and have a configuration similar to other narrow pull-apart basins, e.g., [74]. In fact, both these lakes have been interpreted as such by [173]. However, Höskuldsvatn sits in a WNW shallow depression in an eroded flat land without a major fault controlling its southern flank. This configuration indicates that the lake might be the expression of a dissymmetric extensional structure. As the two lakes are at 
the release zones of WNW and NW strike-slip faults, they are likely rhomb-graben formed at the bends of these segmented shear faults.

\section{Interpretations}

\subsection{The Structural Architecture}

The structural features interpreted below are the overall fracture pattern, basins and highs, plate boundaries, and briefly the geothermal activity and pockmarks (Figure 11 and Figure 12(a)).

1) The detailed segmentations of individual faults (Figure 3(a)) are summarised as single fracture traces on the interpreted tectonic map (Figure 11) where the basins and highs are highlighted in colours, and the regional structures of Areas 1 to 6 are also reported. The tectonic pattern shows that the N-S normal faults parallel to the rift/ridge co-exist with the NNE/ENE sinistral and the WNW/NW dextral strike- and oblique-slip Riedel shears of the transform zone and the oblique rift. This pattern extends homogeneously from land to sea and is associated with all structures at and between the plate boundaries. In general, the long parallel ENE shear zones cut the regional offshore and onshore structures diagonally, while the other sets contribute more to basin and high formation.

2) Most of the study area consists of highs into which the basins are carved. The Eyjafjarðaráll, Skjálfandi and Öxarfjörður major basins are predominantly offshore, but as the seafloor elevates along their axes, the structures continue as topographic faulted lows onshore. The N-S faults flank most of Eyjafjarðaráll, Skjálfandi, and the grabens in Theistareykir. As to the Riedel shears, the NW dextral oblique-slip faults delimit Öxarfjörður as well as a narrow basin merging with west of Eyjarfjarðaráll. In the continuation of this latter NW graben, other NW segments extend from the Grímsey High to Flateyjarskagi onshore. After the bend of the Eyjafjarðaráll to WNW along the dextral oblique-slip of the HFF, the basin bifurcates to the south of this transform segment into narrower NE and NW graben structures. To its north, Skjálfandi bends gently to NW within GOR and merges with shorter ENE, NNE, WNW, NW and N-S basins there. But to the south, Skjálfandi splits into narrow NW basins onshore. The width of the offshore basins is rather similar, i.e., $13 \mathrm{~km}$ in Eyjafjarðaráll (WNW section), $12.5 \mathrm{~km}$ in Skjálfandi (N-S portion), and $10-15 \mathrm{~km}$ in Öxarfjörður. The NW-striking Eyjafjörður basin is the narrowest with $\sim 3 \mathrm{~km}$.

3) Due to fault block compartmentalisation, the biggest high appears to be Grímsey-Flateyjarskagi, which has an overall NW trend and extends from sea to land. The outer edges of the Grímsey High are likely bounded by N-S normal, NNE sinistral and NW dextral oblique-slip faults offshore, and those of Flateyjarskagi by NW faults onshore. The HFF and DL both cut the Grímsey-Flateyjarskagi High. Mánáreyjar-Tjörnes is the other major high bounded by N-S faults to the east. As earlier stated, the western boundary of 
the Tjörnes High lacks clear faulting onshore (Figure 8(c)), but offshore it is likely flanked by the N-S fault of Skjálfandi, thus defining a horst structure for the Mánáreyjar-Tjörnes High. Another high is the narrow horst to the north of Skagafjörður-Tröllaskagi, bounded by the NE sinistral oblique-slip faults (Figure 11).

4) The volcanic edifices of the K-R are organised N-S, and those of Stóragrunn, Hóllinn and Nafir in GOR are known to be within the NW left-stepping en échelon segments, reflecting a dextral motion along this oblique rift [137]. Two volcano-tectonic features are interpreted in the present study. One is that the volcanism is in fact distributed in three NW en échelon segments, which include the totality of Mánáreyjar (Figure 12(a)). The other is the specific organisation of the volcanic edifices within each of the NW segments. The volcanic edifices in Stóragrunn and Hóllinn are likely within N-S left-stepping en échelon structures, also typical of dextral motion, while the smaller edifices in Nafir are aligned WNW and NW, or they are on shorter ENE sinistral faults. In Mánáreyjar, however, volcanism is clearly N-S to the south but WNW/NW farther north. This change of strike from N-S to WNW/NW occurs at the intersection of this volcanic segment and the ENE sinistral shear zones of Area 1.

5) Geothermal activity and pockmarks are recognised mostly onshore and found locally offshore [118] [150] [151]. Although the offshore manifestations are fracture-controlled, their tectonic settings are poorly known in detail. Their position compared to the structures of the tectonic map, however, indicates that the same extensional faults and Riedel shears controlling the basins, horsts and volcanism (Figure 11) likely control also these manifestations. To reiterate, these N-S normal, NNE/ENE sinistral and WNW/NW dextral oblique-slip fault sets play the critical role in the geological processes and the geothermal activity of the prominent Theistareykir geothermal site onshore [169].

\subsection{Configuration of Plate Boundaries and the Microplate}

Chirp data (Multibeam and high resolution shallow seismic reflection) in the Skjálfandi Basin indicate that the seafloor and some $50 \mathrm{~m}$ of underlying Holocene sediments are displaced $<100 \mathrm{~m}$, vertically [136] [137]. The following interpretations, however, concern the deformation that has been ongoing over longer geological time scale and is more complex than the present-day or post-glacial tectonic activity.

1) The Mánáreyjar volcanic segment of the GOR is not a relay zone between the Skjálfandi and Öxarfjörður Basins (Figure 12(a)). The Öxarfjörður Basin strikes parallel to the Mánáreyjar volcanic segment, is flanked by NW dextral oblique-slip faults, and falls coherently in the continuation of the GOR. Therefore, the basin is likely one of the en échelon segments of this oblique rift (Figure 12(b)). As a consequence, the GOR would be at least $150 \mathrm{~km}$ 
long, before merging with the NRZ onshore.

2) The number of major structures on each side of Grímsey is uneven and raises questions about the configuration of the plate boundaries and the extent of the microplate. It is emphasised that due to unclear magnetic anomalies to the north of TFZ, e.g., [122], and the absence of geodetic measurements offshore, the following interpretation is purely speculative and relies on the geometry of the structures and kinematic considerations.

The American Plate separates from west of Grímsey across the $10-13 \mathrm{~km}$ wide K-R/Eyjafjarðaráll. To the east of Grímsey on the Eurasian Plate, spreading occurs in the presence of the Skjálfandi and Öxarfjörður Basins with a total width of $\leq 27.5 \mathrm{~km}$ (Figure 12(c)). As the GOR is at the plate boundary, contains Öxarfjörður, and extends into the active NRZ onshore (Figure 12(d)), Skjálfandi Basin falls outside of the plate boundary. The DL is the last known segment of the transform plate boundary to the south onshore. It is likely that the small NNE basin to the north of Skagafjörður and Tröllaskagi is also a part of the western plate boundary of Eyjafjarðaráll/K-R. Given these configurations, the microplate caught between these plate boundaries is much larger than the Grímsey High alone, as it would include the highs of Mánáreyjar, Tjörnes, Flateyjarskagi, and Tröllaskagi. This major microplate, labelled as Grímsey-TjörnesDalvík Microplate here (GTDM), presents an overall rhomb geometry (Figure 12(e)). Skjálfandi and Eyjafjörður are two oblique-slip basins inside this microplate. It should be noted that a similar rhomb structure bounded by the $\mathrm{K}-\mathrm{R} /$ Eyjafjarðaráll, GOR, NRZ, and the HFF instead of the DL, appears in the present-day kinematics monitored by GPS measurements, earthquakes and volcanism [139].

\subsection{The Deformation at Depth}

The interpreted topographic and Multibeam/Single beam bathymetric cross-sections, as well as seismic reflection profiles show the extent of the mapped structures into the upper crust (Figures 13(a)-(e)). The section A-A' (GOR to Tröllaskagi) is $80 \mathrm{~km}$ long, the section B-B' (Eyjafjarðaráll to Öxarfjörður) $120 \mathrm{~km}$, but the seismic profiles cover only a portion of these sections. The stratigraphy on the seismic profiles is equivalent to the onshore Plio-Pleistocene Tjörnes sediments above the upper Tertiary basement. Both the summarised fault traces (Figure 11) and the detailed fracture segments (Figure 3(a)) are reported on the four sections to reflect the contribution of all structures at depth. The selected seismic lines are two of the six 2D vintage profiles acquired in 1985 offshore North Iceland. The six profiles were subject to an initial tectonic interpretation [132] [133], and the line F-4-85 was recently re-interpreted for the NAGTEC Atlas [174]. The interpretation of the seismic profiles below uses the same velocities for the stratigraphy as [133], and benefits from the comprehensive regional tectonic maps, which were not available to those previous interpretations. 
1) The 1.8 seconds two-way travel time (TWT) indicative of sediment thickness on the Iceland Shelf [175], correlates overall with the younger sedimentary sequence showing regular reflectors above a rough basement (Figures 13(c)-(d) and Figures 13(f)-(g)). The contact between the two formations, however, undulates in detail, reflecting an erosional character. It is as shallow as $0.5 \mathrm{~s}$ (TWT), representing a sedimentary sequence with $\sim 0.45 \mathrm{~km}$ thickness (F-4-85), and as deep as $\sim 2.8$ s (TWT) corresponding to a thicker sequence of up to $\sim 3.5 \mathrm{~km}$ (F-6-85). In the upper sediments, thin formations carve locally into the regular reflectors and resemble channel infilling. But on F-6-85, three additional units, likely sedimentary, appear between the basement and the upper regular reflectors (Figure 13(c) and Figure 13(d)). The westernmost of these units (1) is without reflectors and passes laterally to the reflectors of unit 2 that is covered by the reflectors of the youngest unit 3 . The units 1 and 3 are each $\sim 1 \mathrm{~km}$ thick, and unit $2 \sim 0.8 \mathrm{~km}$. The unit 2 in particular, is heavily broken in its top.

2) The mapped N-S normal, the NE/ENE sinistral and the WNW/NW dextral oblique-slip faults (Figure 3(a) and Figure 11) control the basins and highs down to at least $2.8 \mathrm{~s}$ (TWT) or $3.5 \mathrm{~km}$ depth (Figures 13(b)-(f)). Faults display antithetic, synthetic and hourglass geometries, and shallow basins are fully subsided in the upper $1 \mathrm{~km}$ of the crust. Where the Riedel shears control the basins, the grabens are within flower structures above deeper strike- to oblique-slip faults such as parts of Eyjafjörður, Skjálfandi and Öxarfjörður Basins. On all sections, the number of faults is clearly greater at depth compared to the structures mapped on the seafloor, as some of the deep faults do not reach the surface. The dip-slips of the faults are also greater at depth (hundreds of metres), but much less on the seafloor $(\leq 100 \mathrm{~m}$ in general but up to $200 \mathrm{~m}$ on the NW boundary fault of Skjálfandi in GOR).

3) Three major faults (F1 to F3) with wide deformation zones control most of the tectonic-sedimentary processes on each seismic profile. On sections A-A' and F-4-85, they are the HFF (F1), which dips towards the northeast offshore, as well as the NW-striking dextral oblique-slip faults F2 and F3 to the east of the Eyjafjörður Basin on Flateyjarskagi (Figure 13(c) and Figure 13(f)). On the foot wall of F1, a narrow horst is pinched between this fault and F2 and the top of the basement is uplifted to $\sim 0.5 \mathrm{~s}(\sim 0.45 \mathrm{~km}$ depth). The F2 and F3 form a graben, which has antithetic, synthetic and hourglass internal faults, and sits above a basement elevated to $1 \mathrm{~s}(0.9 \mathrm{~km}$ depth). On the hanging wall of $\mathrm{F} 1$, the basement top is at $1.8 \mathrm{~s}(\sim 1.8 \mathrm{~km}$ depth), and the upper sedimentary reflectors are relatively flat on the GTDM, but severely deformed across F1. There, the WNW section of the Eyjafjarðaráll appears as a narrow basin near the surface but it widens to $5 \mathrm{~km}$ between $0.5 \mathrm{~s}$ and $1 \mathrm{~s}$ (0.45 and $0.9 \mathrm{~km}$ depth) and includes a local horst. At these depth intervals, the sedimentary formations are dragged downward by the motion of F1 and thicken within the basin, reflecting the syn-sedimentary activity of this fault. 
On sections B-B' and F-6-85, the N-S faults F1 to F3 extend from the sediments to the basement (Figure 13(e) and Figure 13(f)). The F1 and F2 dip westward and have parallel segments. The F3 is eastward dipping in its lower part, but its segments are shifted to the east above $2 \mathrm{~s}(\sim 2.1 \mathrm{~km})$ in the upper sediments. The sedimentary reflectors are flatter on the foot walls of F1 and F3 where the deformation is milder. On the platform to the east of $\mathrm{F} 1$, the reflectors dip gently westward where an extensional flower structure above a deep strike-slip fault zone is the most obvious structure. On the platform to the west of F3, the middle reflectors dip westward and are covered unconformably by shallower horizontal formations, but at their basis, the sedimentary unit 1 is titled eastward towards F3 and resembles a major landslide. The F1 to F3 define the Eyjafjarðaráll Basin, which is filled by sediments dipping eastward towards the F2 and F1. The F2 and F3 deepened this basin down to $2.8 \mathrm{~s}(\sim 3.5 \mathrm{~km})$ and created the accommodation space for thicker and severely deformed sediments. A syn-sedimentary rollover and onlaps of the sediments onto the basement and F2 are particularly well visible in the thickest part of the basin between $2.8 \mathrm{~s}$ and $1 \mathrm{~s}$ ( $3.5 \mathrm{~km}$ to $0.9 \mathrm{~km}$ depth). From $0.5 \mathrm{~s}$ to $2.8 \mathrm{~s}$ (0.45 to $3.5 \mathrm{~km}$ depth), the Eyjafjarðaráll appears as a half graben, i.e., a geometry likely inherited from the basement (Figure 13(f)). The half graben is $\sim 10 \mathrm{~km}$ wide at depth, but above the sedimentary unit $2(\sim 1.7 \mathrm{~s})$, the basin is narrower with $<5 \mathrm{~km}$ width and is relatively symmetric. These configurations indicate a migration of the axis of this basin in time. The westward dipping NNE en échelon sinistral faults in the continuation of the NE horst of Skagafjörður-Tröllaskagi clearly spread outside of the Eyjafjarðaráll Basin above $1.7 \mathrm{~s}$.

Although the deformation cannot be dated absolutely, the polyphase tectonic is evident from these profiles, with reactivation of the upper Miocene-lower Pliocene faults and syn-sedimentary deformation. The most severe structural phase is speculatively prior to upper Pleistocene-Holocene as it is sealed by the reflectors at $0.6 \mathrm{~s}$ ( $\sim 0.6 \mathrm{~km}$ depth), above which only some of the faults remained active, bounding the basins and highs on the seafloor (Figure 13(e) and Figure 13(f)).

Additionally, the dip values of the faults and the thickness of intrusions must be commented on. For this, a comparison is made with the outcrops of the Icelandic crust in West Iceland where both the age and the level of erosion (1 and $1.5 \mathrm{~km}$ ) are better known than in the study area in North Iceland. Such comparison provides valuable information for the structures at similar depths on the seismic profiles. First, faults dip $80^{\circ}-85^{\circ}$ in the sediments and $75^{\circ}-70^{\circ}$ in the basement on the seismic profiles. These dip values, which were also noted by [133] on all the six vintage profiles, are identical to the faults in West Iceland [72] [176]. These dip values exclude listric faults on the profile, especially in the absence of thick clay and salt layers. Secondly, sills and dykes are important structures as dykes contribute to spreading, and both greatly to the build-up of the crust and fluid circulation. Therefore, their interpretation at depth on seis- 
mic profiles is important. However, the window of West Iceland shows that down to 1 and $1.5 \mathrm{~km}$ crustal depths the thickness of sills and even repeatedly injected dykes is no more than $15 \mathrm{~m}$ and $8.5 \mathrm{~m}$, respectively (Figure 4(d) and Figure 4(e)). Such intrusions are too thin to be detected at the same depths on the vintage seismic profiles.

\subsection{Selected Earthquakes}

The earthquake swarms of 1994-2016 (SIL network, IMO), along with sixteen focal mechanisms from 1994-1997 [108], and 2013 [142] are interpreted in light of the regional structures (Figures 14(a)-(c)). Some clarifications must be made prior to the interpretation. The earthquake swarms of 1994-2016 are up to M 4, and generally between 2 and $10 \mathrm{~km}$ depth. They include three categories of events. Firstly, the majority of the earthquakes in the Eyjafjarðaráll and Öxarfjörður Basins, the HFF offshore, GOR, Grímsey, Tröllaskagi, Flatey and Theistareykir reflects the transform mechanism. Secondly, some of these earthquakes are known to be associated with fluid migration such as in GOR [177], and in the Theistareykir geothermal field [143], but they can also be induced by geothermal operations, e.g., [178]. Thirdly, to the east of the study area (Figure 14(a) and Figure 14(b)), the 1994 to 2016 earthquakes also include a N-S lineation. This lineation reflects the post-rifting deformation [179] related to the repeated Krafla dyke injections of 1975-1984 that led to the northward migration of earthquakes [180], surface faulting and ground widening [181]. Regardless of category, the correlation of the earthquakes and the identified structures brings new insights to the tectonic deformation:

1) The earthquakes are distributed along the trace of the HFF. To the west of this fault, however, the earthquakes fall within at least two WNW left-stepping en échelon segments, which onlap the fault and are conformable with the dextral motion of this transform segment. The earthquake cluster in the WNW section of the Eyjafjarðaráll Basin is within the WNW faults bounding the basin and displays both dextral and normal-slip (Figure 14(b)), while the focal mechanisms inside the basin show only dextral strike-slip motion (Figure 14(c)). These features are evidence of polyphase tectonic where the earthquakes only show the present-day activity of the underlying WNW structures. Furthermore, the earthquake cluster is denser to the east of the NE sinistral oblique-slip shear zone of north SkagafjörðurTröllaskagi, indicating a block compartmentalisation by that zone at depth. The earthquakes are more diffuse beyond the NE shear zone in the N-S section of Eyjafjarðaráll, where they align on the mapped NNE/ENE sinistral, as well as the WNW and NW short dextral strike-slip segments (Figures 14(a) and Figure 14(b)).

2) Most focal mechanisms show either dextral slip on WNW/NW or sinistral slip on NNE fault planes along GOR. The exception is in Nafir where the sole earthquake with a N-S normal-slip focal mechanism falls on the mapped 
boundary fault of the Skjálfandi Basin there (Figure 14(c)).

3) The earthquakes in GOR are organised in two overall groups. One is an isolated NW cluster around Stóragrunn and relatively confined within the plate boundary. The other is the main cluster, striking WNW and extending from Nafir to Öxarfjörður. As this latter WNW cluster clearly cuts the structures of Skjálfandi, Mánáreyjar and Öxarfjörður diagonally, it indicates that earthquakes are not always ruptures of underlying older structures (Figure 14(b)). Within the Öxarfjörður Basin, the cluster delimits a WNW rectangular block in absence of clear fault traces. This may indicate the existence of WNW blind segments of the transform zone/oblique rift, which have not broken the surface.

4) The overall earthquake cluster of GOR is interrupted in three places (Figure 14(a)). The first is a local gap located to the northwest of Nafir, and coincides with a small ENE basin on short sinistral oblique-slip faults. This gap and the basin fall on the trace of the ENE sinistral shear zone that controls the NE-striking horst to the north of Skagafjörður-Tröllaskagi. Half way between Grímsey and Mánáreyjar, the cluster is again interrupted on a NNE seismic lineation that extends southwestwards to the north of the HFF at the latitude of Flatey and is within the ENE sinistral shear zone of Area 1 (Figure 5). Focal mechanism shows possible sinistral motion on this and surrounding NNE seismic lineations [141]. The third interruption is a narrow zone farther to the southeast where the N-S faults of Mánáreyjar are dragged to NNE by the dextral motion of the NW boundary fault of the Öxarfjörður Basin. Even a local interruption of the cluster within the Öxarfjörður Basin aligns on the continuation of one of these rotated NNE faults.

The interpretation of the 1994-2016 earthquakes only exposes the recent ruptures of the pure extensional and shear fault sets. Widespread variations in the maximum horizontal stress $\left(\mathrm{S}_{\text {Hmax }}\right)$ are known in both the paleostress since the upper Tertiary [67] [182] [183], and in the stress map of North Iceland deduced from earthquakes, borehole measurements and older geological indicators [184]. These variations are responsible for normal and strike-slip faulting on a range of Tertiary to present fault sets, identical to the structures here. The earthquakes reflect mostly reactivation of underlying structures but, additionally, they could indicate the activity of a new plate boundary. It is speculated that the WNW earthquake cluster cutting the NW en échelon segments of GOR in Skjálfandi, Mánáreyjar and Öxarfjörður diagonally corresponds to either a young horsetail splay of the underlying structures, or to the initiation of a new segment at GOR (Figure 14(d)). In fact, among the three segments of the transform zone, GOR is known to be at the youngest stage of development [108].

\section{Conclusions and Discussions}

The comprehensive regional tectonic map offshore and onshore North Iceland provides a continuous coverage of the structural pattern of rift, oblique rift, 
transform segment and a major microplate. About 2258 fractures were identified on high resolution Multibeam, Single beam and satellite images. The structures are faults, open fractures, prominent joints, eruptive craters onshore, and marine volcanic edifices offshore, but dykes are not visible on the images. Their qualitative and quantitative multidisciplinary structural analysis, and correlation with selected data, show the range and complexity of the deformation at and between these plate boundaries. The structural pattern consists of six sets of normal and shear fractures, reflecting the effect of rifting and transform faulting. These sets have been active in a polyphase tectonic since upper Tertiary during which, they have formed the basins and horsts; compartmentalised the blocks at any scale; induced fault drags, block rotation, syn-sedimentary deformation; and controlled the volcanism.

\subsection{Main Conclusions}

The main results regarding the structural pattern (Figure 15(a)), the configuration of plate boundaries and a microplate (Figure 15(b)), the styles of deformation above deep-seated shear zones (Figures 15(c)-(e)), or associated with structures that have fully broken the surface (Figures $15(\mathrm{f})-(\mathrm{k})$ ) are as follows:

- All sets have dip-slips. The N-S faults are purely extensional, but the surface expression of deeper strike-slip zones are left- and right-stepping en échelon segments, indicating dextral motion on WNW and NW, and sinistral motion on NNE to ENE faults. Shear motion could not be identified on the E-W set.

- Faults are segmented, ranging in total length from $\sim 1 \mathrm{~km}$ to a maximum of $30 \mathrm{~km}$. Individual segments of a single fault can dip in opposite directions as faults are steeply-dipping $\left(85^{\circ}-70^{\circ}\right.$ in the upper crust) and some have not fully coalesced, such as the HFF.

- The N-S normal faults form $39 \%$, and the oblique-slip Riedel shears $61 \%$ of the fracture population of which, the NW, NNE and ENE faults are the most frequent. The WNW faults, including the HFF, are though less frequent, and the $\mathrm{E}-\mathrm{W}$ fractures the least of all.

- The study area is dominantly highs onto which narrow basins are carved. The N-S, NW, and to a lesser degree the WNW and NNE/NE sets, contribute more than the NE/ENE sets to basin and horst formation such as in the Eyjafjarðaráll, Skjálfandi, Öxarfjörður, Eyjafjörður and Theistareykir Basins, as well as the Grímsey-Flateyjarskagi and Mánáreyjar-Tjörnes Highs. The NE/ENE sets are mostly long parallel shear zones cutting the regional offshore and onshore structures diagonally.

- Within the rift, oblique rift, and the transform zone, magma injects into the N-S normal faults, the Riedel shears, or at the intersections of these fault types. Magma injection into shear faults indicates that the oblique rift and the transform zone are leaky.

- Marine volcanism pierces the K-R and the Mánáreyjar High. A startling feature is that these ridges evolve into basins southward, a configuration labelled 
as "along-axis Ridge to Basin" here. The proportion of ridge $(70 \mathrm{~km})$ to basin $(65 \mathrm{~km})$ is balanced for the K-R and the Eyjafjarðaráll Basin, but uneven for Mánáreyjar $(90 \mathrm{~km})$ and Theistareykir $(\geq 25 \mathrm{~km})$.

- The range of deformation associated with shear fractures includes horsetail splays (e.g., HFF and Stórihver Fault); rhomb-graben in relay zone of strike-slip faults (e.g., HFF); and the rotation of the rift structures by dextral strike-slip motions of the HFF and by the boundary fault of the Öxarfjörður Basin.

- The mapped faults extend to 4 - $5 \mathrm{~km}$ depth, cutting the volcanic and sedimentary crust of upper Miocene-present (Figure 13). Listric faults are absent and the steeply dipping faults display antithetic and synthetic geometries and occasionally form extensional flower structures on deeper strike-slips.

- The tectonic is most intense along the HFF and Eyjafjarðaráll Basin where the reactivated basement faults deepened the basin as a half graben, creating accommodation space for thicker sediments, syn-sedimentary deformation, roll-over, and sediment onlaps. Most of the structuring is prior to the upper Pleistocene-Holocene, hence an upward decrease in the number and the dip-slip of the faults. Some of the faults are still active, bounding the basins and highs on the seafloor.

- The American plate separates along the narrower K-R/Eyjafjarðaráll, and the Eurasian Plate across a wider zone including the Skjálfandi and Öxarfjörður Basins. Öxarfjörður is likely one of the NW en échelon segments of GOR and merges with the active NRZ. The outer plate boundaries of GOR/NRZ, DL, $\mathrm{K}-\mathrm{R} /$ Eyjafjarðaráll isolate a major rhomb-shaped microplate labelled as Grímsey-Tjörnes-Dalvík. The Skjálfandi and Eyjafjörður are basins on oblique-slip faults within this microplate.

- The earthquake cluster and focal mechanisms match the overall traces and motions of the mapped structures in the HFF and GOR, but a few gaps in the cluster coincide with the ENE shear zones or with the rotated underlying faults. The long WNW earthquake cluster in GOR cuts diagonally the older structures and could correspond either to a blind splay fault, or to the initiation of a new segment of plate boundary parallel to the HFF.

\subsection{Discussions}

This paper presents a range of deformation resulting from a polyphase tectonic since the upper Miocene, while its last stages from Holocene to the active deformation have received more attention. Some discussions on these results and other contributions are appropriate.

- The younger mapped structural features are in good agreement with previous studies of marine volcanoes and the Holocene N-S faults offshore and onshore North Iceland [137] [159] [160] [161] [162] [163]. However, the six sets of extensional and shear faults identified here are not isolated, but typical of areas where diverging plate boundaries interact such as West Iceland [72], 
South Iceland [73], and Southwest Iceland [80]. The key feature in all these areas is that the Riedel shears are roughly $2 / 3$ of the fracture population and the rift-parallel structures only $1 / 3$.

- Despite a hotspot, the regional partitioning of rift/ridge segments, transform/transfer zones, parallel basins, fracturing and volcanism oblique to the rift seen in North Iceland are identical to diverging plate boundaries of similar age in other continental and oceanic contexts, e.g., [44] [81] [82]. Similarly, specific structural features of North Iceland are also in good agreement with combined extensional and Riedel shears pattern [68] [70] [83], en échelon and sinuous fractures above deep-seated shear zones [50] [51], horsetail splays [28] [52], and rhomb graben in release zones [34] [37] described elsewhere.

- Hydrocarbon is the most extensively exploited natural resource associated with diverging plate boundaries, where extensional and shear fractures also control the magmatic heat source, permeability and geothermal fluid flow [5] [44] [57] [80] [185]. Although the pockmarks and the geothermal activity are occasionally detected offshore North Iceland, further exploration of these prospects requires a regional tectonic frame and detailed structural pattern, which are provided by this present contribution. Similar tectonic already proved to control the geothermal activity in Theistareykir [169].

A few of the obtained results, however, may diverge from previous findings:

- The short NNE fault segments of the Eyjafjarðaráll Basin to the north of the HFF [161] [162] may appear as a part of the N-S boundary faults of the basin. However, these segments cannot act as boundary faults as they all dip towards north-northwest, occupy the width of the basin and expand outside of it. These NNE structures are with typical en échelon arrangement and sinuosity, and they are sinistral oblique-slip faults above deep-seated ENE shear zones (Figure 11).

- The en échelon NW segments have been reported as surface expression of the WNW-striking HFF onshore [164]. Such geometry was observed along the strike-slip faults of all sets in Theistareykir [167] [168] [172], and more regionally in this study.

- The dextral offset of the HFF onshore is estimated at $100 \mathrm{~km} \mathrm{[101]} \mathrm{or} 140 \mathrm{~km}$ [117], which is cumulative since the upper Tertiary. On the map (Figure 11), the HHF cuts the onshore and offshore structures of Mánáreyjar, Tjörnes, Skjálfandi, Flateyjarskagi, Eyjafjörður and the horst and graben to the north of Skagafjörður-Tröllaskagi without significant horizontal offset. The present structural configuration is, therefore, the latest stage of the activity of this transform segment and further evidence of polyphase tectonic.

- The moraines and glacial sediments of the last glaciation cover the Iceland shelf and present a strong morphology on images. It can be argued that some of the mapped structures on the seafloor are not of tectonic origin but morphostructures of glacial origin. Considering that the glaciation ended at 
14,000 yr BP [135], time has been sufficient for the faulting of all sediments with the seafloor during the continuous tectonic activity associated with plate boundaries. Even a few decades of earthquake monitoring shows the high frequency of fault ruptures and their widespread strikes. In fact, the offshore "morphostructures" mentioned above are faults, which extend from the seafloor into the crust and contribute to the tectonic deformation at depth (Figure 13).

\section{Acknowledgements}

The authors thank Bryndís Brandsdóttir (Institute of Earth Sciences, University of Iceland), Guðrún Helgadóttir (Marine and Freshwater Research Institute), Hilmar Helgason (Icelandic Coast Guard), and Thórarinn S. Arnarson (National Energy Authority of Iceland-Orkustofnun) for their permissions to use the Multibeam and Single beam bathymetric data. Thórarinn S. Arnarson also permitted us to use the two seismic profiles on Figure 13. At ÍSOR our special thanks go to Ögmundur Erlendsson for providing higher resolution bathymetric maps and vintage 2D seismic profiles; Albert Albertsson and Guðrún Sigríður Jónsdóttir for their support with GIS; Árni Ragnarsson for the statistical analysis and Bjarni Richter for encouragement. The authors also thank the anonymous reviewers of the International Journal of Geosciences for constructive comments, as well as the Assistant Editor, Beverly Guo, for support during publishing process.

\section{Conflicts of Interest}

The authors declare no conflicts of interest regarding the publication of this paper.

\section{References}

[1] Wilson, J.T. (1965) A New Class of Faults and Their Bearing on Continental Drift. Nature, 207, 343-347. https://doi.org/10.1038/207343a0

[2] Sykes, L.R. (1967) Mechanism of Earthquakes and Nature of Faulting on the Mid-Oceanic Ridges. Journal of Geophysical Research, 72, 2131-2153. https://doi.org/10.1029/JZ072i008p02131

[3] Vine, F.J. and Matthews, D.H. (1963) Magnetic Anomalies over Oceanic Ridges. Nature, 199, 947-949. https://doi.org/10.1038/199947a0

[4] Cole, J.W. (1990) Structural Control and Origin of Volcanism in the Taupo Volcanic Zone, New Zealand. Bulletin of Volcanology, 52, 445-459. https://doi.org/10.1007/BF00268925

[5] Acocella, V., Korme, T., Salvini, F. and Funiciello, R. (2002) Elliptic Calderas in the Ethiopian Rift: Control of Pre-Existing Structures. Journal of Volcanology and Geothermal Research, 119, 189-203. https://doi.org/10.1016/S0377-0273(02)00342-6

[6] Wilson, C.J.N., Gravley, D.M., Leonard, G.S. and Rowland, J.V. (2009) Volcanism in the Central Taupo Volcanic Zone, New Zealand: Tempo, Styles and Controls. In: Thordarson, T., Self, S., Larsen, G., Rowland, S.K. and Hoskuldsson, Á., Eds. Studies in Volcanology: The Legacy of George Walker, Special Publications of IAVCEI, Vol. 
2, 225-247.

[7] White, D.E. (1965) Geothermal Energy. U.S. Geological Survey Circular, 519, Washington DC, 17 p. https://doi.org/10.2172/7306829

[8] Keir, D., Hamling, I.J., Ayele, A., Calais, E., Ebinger, C., Wright, T.J., Jacques, E., Mohamed, K., Hammond, J.O.S., Belachew, M., Baker, E., Rowland, J.V., Lewi, E. and Bennati, L. (2009) Evidence for Focused Magmatic Accretion at Segment Centers from Lateral Dike Injections Captured Beneath the Red Sea Rift in Afar. Geology, 37, 59-62. https://doi.org/10.1130/G25147A.1

[9] Ebinger, C., Ayele, A., Keir, D., Rowland, J., Yirgu, G., Wright, T., Belachew, M. and Hamling, I. (2010) Length and Timescales of Rift Faulting and Magma Intrusion: The Afar Rifting Cycle from 2005 to Present. Annual Review of Earth Planetary Science, 38, 439-466. https://doi.org/10.1146/annurev-earth-040809-152333

[10] Ostenso, N.A. (1968) Geophysical Studies in the Greenland Sea. Geological Society of America Bulletin, 79, 107-132. https://doi.org/10.1130/0016-7606(1968)79[107:GSITGS]2.0.CO;2

[11] Vogt, P.R., Ostenso, N.D. and Johnson, L. (1970) Magnetic and Bathymetric Data Bearing on Sea-Floor Spreading North of Iceland. Journal of Geophysical Research, 75, 903-920. https://doi.org/10.1029/JB075i005p00903

[12] Shih, J. and Molnar, P. (1975) Analysis and Implications of the Sequence of Ridge Jump that Eliminated the Surveyor Transform Fault. Journal of Geophysical Research, 80, 4815-4822. https://doi.org/10.1029/JB080i035p04815

[13] Atwater, T. (1981) Propagating Rifts in Sea Floor Spreading Patterns. Nature, 290, 185-186. https://doi.org/10.1038/290185a0

[14] Kleinrock, M. and Hey, R.N. (1989) Migrating Transform Zone and Lithospheric Transfer at the Galapagos $95.5^{\circ} \mathrm{W}$ Propagator. Journal of Geophysical Research, 94, 13859-13878. https://doi.org/10.1029/JB094iB10p13859

[15] Khodayar, M. and Franzson, H. (2007) Fracture Pattern of Thjórsárdalur Central Volcano with Respect to Rift-Jump and a Migrating Transform Zone in South Iceland. Journal of Structural Geology, 29, 898-912. https://doi.org/10.1016/j.jsg.2006.11.007

[16] Einarsson, P. (2008) Plate Boundaries, Rifts and Transforms in Iceland. Jökull, 58, 35-58.

[17] Nunns, A.G. (1983) Plate Tectonic Evolution of the Greenland-Scotland Ridge and Surrounding Regions. In: Bott, M.H., Saxov, S., Talvani, M. and Thiede, J., Eds., Structure and Development of the Greenland-Scotland Ridge, New Methods and Concepts, Plenum Press, New York and London, 11-30.

[18] Withjack, M.O. and Jamison, W.R. (1986) Deformation Produced by Oblique Rifting. Tectonophysics, 126, 99-124. https://doi.org/10.1016/0040-1951(86)90222-2

[19] Hey, R.N. and Vogt, P. (1977) Spreading Center Jumps and Sub-Axial Asthenosphere Flow near the Galapagos Hotspot. Tectonophysics, 37, 41-52. https://doi.org/10.1016/0040-1951(77)90038-5

[20] Engeln, J.F., Stein, S., Werner, J. and Gordon, R.G. (1988) Microplate and Shear Zone Models for Oceanic Spreading Center Reorganizations. Journal of Geophysical Research, 93, 2839-2856. https://doi.org/10.1029/JB093iB04p02839

[21] Hey, R., Martinez, F., Höskuldsson, Á. and Benediktsdóttir, Á. (2010) Propagating rift Model for the V-Shaped Ridges South of Iceland. AGU, Geochemistry, Geophysics, Geosystems, 11, Q03011, 24 p. 
[22] Karson, J.A. (2017) The Iceland Plate Boundary Zone: Propagating Rifts, Migrating Transforms, and Rift-Parallel Strike-Slip. AGU, Geochemistry, Geophysics, Geosystems, 18, 4043-4054. https://doi.org/10.1002/2017GC007045

[23] Freund, R. (1970) Rotation of Strike-Slip Faults in Sistan, Southeastern Iran. Journal of Geology, 78, 188-200. https://doi.org/10.1086/627500

[24] Tapponnier, P., Armijo, R., Manighetti, I. and Courtillot, V. (1990) Bookshelf Faulting and Horizontal Block Rotations between Overlapping Rifts in Southern Afar. Geophysical Research Letters, 17, 1-4. https://doi.org/10.1029/GL017i001p00001

[25] Morgan, J.P. and Kleinrock, M.C. (1991) Transform Zone Migration: Implications of Bookshelf Faulting at Oceanic and Icelandic Propagating Ridges. Tectonics, 10, 920-935. https://doi.org/10.1029/90TC02481

[26] Manighetti, I., Tapponnier, P., Gillot, P.Y., Jacques, E., Courtillot, V., Armijo, R., Ruegg, J.C. and King, G. (1998) Propagation of Rifting along the Arabia-Somalia Plate Boundary: Into Afar. Journal of Geophysical Research, 103, 4947-4974. https://doi.org/10.1029/97JB02758

[27] Green, R.G., White, R.S. and Greenfield, T. (2014) Motion in the North Iceland Volcanic Rift Zone Accommodated by Bookshelf Faulting. Nature Geoscience, 7, 29-33. https://doi.org/10.1038/ngeo2012

[28] Christie-Blick, N. and Biddle, K.T. (1985) Deformation and Basin Formation along Strike-Slip Faults. In: Biddle, K.T. and Christie-Blick, N., Eds., Strike-Slip Deformation, Basin Formation, and Sedimentation. Society of Economic Paleontologists and Mineralogists, Special Publication, Vol. 37, 1-34. https://doi.org/10.2110/pec.85.37.0001

[29] Cowan, D.S., Botros, M. and Johnson, H.P. (1986) Bookshelf Tectonics: Rotated Crustal Blocks within the Sovanco Fracture Zone. Geophysical Research Letters, 13, 995-998. https://doi.org/10.1029/GL013i010p00995

[30] Ron, H., Freund, R., Garfunkel, Z. and Nur, A. (1984) Block Rotation by Strike-Slip Faulting: Structural and Paleomagnetic Evidence. Journal of Geophysical Research, 89, 6256-6270. https://doi.org/10.1029/JB089iB07p06256

[31] Mandl, G. (1987) Tectonic Deformation by Rotating Parallel Faults: The "Bookshelf" Mechanism. Tectonophysics, 141, 277-285, and 289-316.

https://doi.org/10.1016/0040-1951(87)90205-8

[32] Bird, R.T., Naar, D., Larson, R.L., Searle, R.C. and Scotese, Ch.R. (1998) Plate Tectonic Reconstructions of the Juan Fernandez Microplate: Transformation from Internal Shear to Rigid Rotation. Journal of Geophysical Research, 103, 7049-7067. https://doi.org/10.1029/97JB02133

[33] Lawrence, R.M., Karson, J.A. and Hurst, S. (1998) Dike Orientations, Fault-Block Rotations, and the Construction of Slow Spreading Oceanic Crust at $22^{\circ} 40^{\prime} \mathrm{N}$ on the Mid-Atlantic Ridge. Journal of Geophysical Research, 103, 663-676. https://doi.org/10.1029/97JB02541

[34] Garfunkel, Z. (1981) Internal Structure of the Dead Sea Leaky Transform (Rift) in Relation to Plate Kinematics. Tectonophysics, 80, 81-108. https://doi.org/10.1016/0040-1951(81)90143-8

[35] Hayward, N.J. and Ebinger, C.J. (1996) Variations in the Along-Axis Segmentation of the Afar Rift system. Tectonics, 15, 244-257. https://doi.org/10.1029/95TC02292

[36] Laughton, A.S. and Searle, R.C. (1979) Tectonic Processes on Slow-Spreading Ridges. In: Talwani, M., Harrison, C.G. and Hayes, D.E., Eds., Deep Drilling Results 
in the Atlantic Ocean: Ocean Crust. Maurice Ewing Series, Vol. 2, American Geophysical Union, 15-32. https://doi.org/10.1029/ME002p0015

[37] Corti, G. (2009) Continental Rift Evolution: From Rift Initiation to Incipient Break-Up in the Main Ethiopian Rift, East Africa. Earth Science Reviews, 96, 1-53. https://doi.org/10.1016/j.earscirev.2009.06.005

[38] Chorowicz, J. (2005) The East African Rift System. Journal of African Earth Sciences, 43, 379-410. https://doi.org/10.1016/j.jafrearsci.2005.07.019

[39] Spinks, K.D., Acocella, V., Cole, J.W. and Bassett, K.N. (2005) Structural Control of Volcanism and Caldera Development in the Transtensional Taupo Volcanic Zone, New Zealand. Journal of Volcanology and Geothermal Research, 144, 7-22. https://doi.org/10.1016/j.jvolgeores.2004.11.014

[40] Vine, F.J. (1966) Spreading of the Ocean Floor; New Evidence. Science, 154, 1405-1415. https://doi.org/10.1126/science.154.3755.1405

[41] Talwani, M. and Eldholm, O. (1977) Evolution of the Norwegian-Greenland Sea. Geological Society of America Bulletin, 88, 969-999.

https://doi.org/10.1130/0016-7606(1977)88<969:EOTNS>2.0.CO;2

[42] Dauteuil, P. and Brun, J.P. (1996) Deformation Partitioning in a Slow-Spreading Ridge Undergoing Oblique Extension (Mohns Ridge-Norwegian Sea). Tectonics, 15, 870-884. https://doi.org/10.1029/95TC03682

[43] Dauteuil, P., Huchon, P., Quemeneur, F. and Souriot, T. (2001) Propagation of an Oblique Spreading Centre: The Western Gulf of Aden. Tectonophysics, 332, 423-442. https://doi.org/10.1016/S0040-1951(00)00295-X

[44] Lamarche, G., Barnes, P.M. and Bull, J.M. (2006) Faulting and Extension Rate over the Last 20,000 Years in the Offshore Whakatane Graben, New Zealand Continental Shelf. Tectonics, 25, TC4005, 24 p.

[45] Mbina Mounguengui, M. and Guiraud, M. (2009) Neocomian to Early Aptian Syn-Rift Evolution of the Normal to Oblique-Rifted North Gabon Margin (Interior and N'komi Basins). Marine and Petroleum Geology, 26, 1000-1017. https://doi.org/10.1016/j.marpetgeo.2008.11.001

[46] Sanderson, D.J. and Marchini, W.R.D. (1984) Transpression. Journal of Structural Geology, 6, 449-458. https://doi.org/10.1016/0191-8141(84)90058-0

[47] Fossen, H. and Tikoff, B. (1998) Extended Models of Transpression and Transtension, and Application to Tectonic Settings. In: Holdsworth, R.E., Strachan, R.A. and Dewey, J.F., Eds., Continental Transpressional and Transtensional Tectonics. Geological Society, London, Special Publications, 135, 15-33.

[48] Agostini, A., Bonini, M., Corti, G., Sani, F. and Mazzarini, F. (2011) Fault Architecture in the Main Ethiopian Rift and Comparison with Experimental Models: Implications for Rift Evolution and Nubia-Somalia Kinematics. Earth and Planetary Science Letters, 301, 479-492. https://doi.org/10.1016/j.epsl.2010.11.024

[49] McClay, K.R. and White, M.J. (1995) Analogue Modelling of Orthogonal and Oblique Rifting. Marine and Petroleum Geology, 12, 137-151. https://doi.org/10.1016/0264-8172(95)92835-K

[50] Wheeler, W.H. and Karson, J.A. (1994) Extension and Subsidence Adjacent to a "Weak" Continental Transform: An Example from the Rukwa Rift, East Africa. Geology, 22, 625-628. https://doi.org/10.1130/0091-7613(1994)022<0625:EASATA >2.3.CO;2

[51] Aydin, A. and Nur, A. (1985) The Types and Role of Stepovers in Strike Slip Tectonics. In: Biddle, K.T. and Christie-Blick, N., Eds., Strike-Slip Deformation, Basin 
Formation, and Sedimentation. Society of Economic Paleontologists and Mineralogists, Special Publication, Vol. 37, 35-44. https://doi.org/10.2110/pec.85.37.0035

[52] Harding, T.P., Vierbuchen, R.C. and Christie-Blick, N. (1985) Structural Styles, Plate-Tectonic Settings, and Hydrocarbon Traps of Divergent (Transtensional) Wrench Faults. In: Biddle, K.T. and Christie-Blick, N., Eds., Strike-Slip Deformation, Basin Formation, and Sedimentation. Society of Economic Paleontologists and Mineralogists, Special Publication, Vol. 37, 51-77. https://doi.org/10.2110/pec.85.37.0051

[53] Clifton, A.E. and Schlische, R.W. (2003) Fracture Populations on the Reykjanes Peninsula, Iceland: Comparison with Experimental Clay Models of Oblique Rifting. Journal of Geophysical Research B: Solid Earth, 108, ETG 4-1-4-17. https://doi.org/10.1029/2001JB000635

[54] Ben-Avraham, Z. and Zoback, M.D. (1992) Transform-Normal Extension and Asymmetric Basins: An Alternative to Pull-Apart Models. Geology, 20, 423-426. https://doi.org/10.1130/0091-7613(1992)020<0423:TNEAAB>2.3.CO;2

[55] Morley, C.K., Nelson, R.A., Patton, T.L. and Munn, S.G. (1990) Transfer Zones in the East African Rift System and Their Relevance to Hydrocarbon Exploration in Rifts. American Association of Petroleum Geologists Bulletin, 74, 1234-1253.

[56] Bellahsen, N., Leroy, S., Autin, J., Razin, P., d’Acremont, E., Sloan, H., Pik, R., Ahmed, A. and Khanbari, K. (2013) Pre-Existing Oblique Transfer Zones and Transfer/Transform Relationships in Continental Margins: New Insights from the Southeastern Gulf of Aden, Socotra Island, Yemen. Tectonophysics, 607, 32-50. https://doi.org/10.1016/j.tecto.2013.07.036

[57] Muirhead, J.D. and Kattenhorn, S.A. (2018) Activation of Preexisting Transverse Structures in an Evolving Magmatic Rift in East Africa. Journal of Structural Geology, 106, 1-18. https://doi.org/10.1016/j.jsg.2017.11.004

[58] Audet, P. and Burgmann, R. (2011) Dominant Role of Tectonic Inheritance in Supercontinent Cycles. Nature Geoscience, 4, 184-187.

https://doi.org/10.1038/ngeo1080

[59] Tesauro, M., Kaban, M.K. and Cloetingh, S. (2012) Global Strength and Elastic Thickness of the Lithosphere. Global and Planetary Change, 90-91, 51-57. https://doi.org/10.1016/j.gloplacha.2011.12.003

[60] Ziegler, P.A. and Cloetingh, S. (2004) Dynamic Processes Controlling Evolution of Rifted Basins. Earth Science Review, 64, 1-50. https://doi.org/10.1016/S0012-8252(03)00041-2

[61] Philippon, M. and Corti, G. (2016) Obliquity along Plate Boundaries. Tectonophysics, 693, 171-182. https://doi.org/10.1016/j.tecto.2016.05.033

[62] Laughton, A.S. (1966) A Discussion Concerning the Floor of the Northwest Indian Ocean-The Gulf of Aden. Philosophical Transactions of the Royal Society of London, A259, 150-171. https://doi.org/10.1098/rsta.1966.0004

[63] Atwater, T. and Macdonald, K.C. (1977) Are Spreading Centres Perpendicular to Their Transform Faults? Nature, 270, 715-719. https://doi.org/10.1038/270715a0

[64] Taylor, B., Goodliffe, A. and Martinez, F. (2009) Initiation of Transform Faults at Rifted Continental Margins. Comptes Rendus Geoscience, 341, 428-438. https://doi.org/10.1016/j.crte.2008.08.010

[65] Delvaux, D. (2001) Tectonic and Palaeostress Evolution of the Tanganyika-RukwaMalawi Rift Segment, East African Rift System. In: Ziegler, P.A., Cavazza, W., Robertson, A.H.F. and Crasquin-Soleau, S., Eds., Peri-Tethys Memoir 6: Peri-Tethyan 
Rift/ Wrench Basins and Passive Margins, Mémoire du Musée National d'Histoire Naturelle, Paris, Vol. 186, 545-567.

[66] Huchon, P. and Khanbari, K. (2003) Rotation of the Syn-Rift Stress Field of the Northern Gulf of Aden Margin, Yemen. Tectonophysics, 364, 147-166. https://doi.org/10.1016/S0040-1951(03)00056-8

[67] Homberg, C., Bergerat, F., Angelier, J. and Garcia, S. (2010) Fault Interaction and Stresses along Broad Oceanic Transform Zone: Tjörnes Fracture Zone, North Iceland. Tectonics, 29, TC1002, 12 p.

[68] Tchalenko, J.S. (1970) Similarities between Shear Zones of Different Magnitude. Geological Society of America Bulletin, 81, 1625-1640. https://doi.org/10.1130/0016-7606(1970)81[1625:SBSZOD]2.0.CO;2

[69] Jóhannesson, H. (1980) Evolution of the Rift Zones in Western Iceland (in Icelandic with English Summary). Náttúrufraedingurinn, 50, 13-31.

[70] Coletta, B. (1981) Réseaux de fractures et derive de la Basse-Californie par rapport au continent Nord-Américain. Comptes Rendues de l'Académie des Sciences, Paris, 292, Series II, 1441-1444.

[71] Mamula, N. and Voight, B. (1985) Tectonic Analysis of Lineaments near a Spreading axis, Northeastern Iceland. Tectonophysics, 116, 63-93. https://doi.org/10.1016/0040-1951(85)90222-7

[72] Khodayar, M., Franzson, H., Björnsson, S., Víkingsson, S. and Jónsdóttir, G.S. (2004) Tectonic Lineaments of Borgarfjörður-Hvalfjörður from Aerial Photographs, West Iceland: Preliminary Results. Iceland GeoSurvey, Report ÍSOR-2004/021, 48 p.

[73] Khodayar, M., Björnsson, S. and Franzson, H. (2011) Hvammsvirkjun, Holtavirkjun, Urriðafossvirkjun: Synthesis of 2001-2010 Geological Data from Hreppar and South Iceland Seismic Zone. Iceland GeoSurvey, Report ÍSOR-2011/032, and Landsvirkjun Report LV-2011/073, 80 p., 11 Maps.

[74] Smit, J., Brun, J.P., Cloetingh, S. and Ben-Avraham, Z. (2008) Pull-Apart Basin Formation and Development in Narrow Transform Zones with Application to the Dead Sea Basin. Tectonics, 27, TC6018, 17 p.

[75] Khodayar, M. (2008) Results of the 2007 Surface Geothermal Exploration in the Asal Rift and Transform Zones, Djibouti: Tectonics and Geothermal Manifestations. Iceland GeoSurvey, Report ÍSOR-2008/008, 70 p.

[76] Waldron, J.W.F. (2005) Extensional Fault Arrays in Strike-Slip and Transtension. Journal of Structural Geology, 27, 23-34. https://doi.org/10.1016/j.jsg.2004.06.015

[77] Brandsdóttir, B., Riedel, C., Richter, B., Helgadóttir, G., Kjartansson, E., Detrick, R., Dahm, T., Mayer, L., Calder, B. and Driscoll, N. (2005) Multibeam Bathymetric Maps of the Kolbeinsey Ridge and Tjörnes Fracture Zone, N-Iceland. Abstract European Geophysical Union General Assembly, Nice, France.

[78] Clifton, A.E. and Kattenhorn, S.A. (2006) Structural Architecture of a Highly Oblique Divergent Plate Boundary Segment. Tectonophysics, 419, 27-40. https://doi.org/10.1016/j.tecto.2006.03.016

[79] Palgan, D., Devey, C.W. and Yeo, I.A. (2017) Volcanism and Hydrothermalism on a Hotspot-Influenced Ridge: Comparing Reykjanes Peninsula and Reykjanes Ridge, Iceland. Journal of Volcanology and Geothermal Research, 348, 62-81. https://doi.org/10.1016/j.jvolgeores.2017.10.017

[80] Khodayar, M., Björnsson, S., Guðnason, E.Á., Níelsson, S., Axelsson, G. and Hickson, C. (2018) Tectonic Control of the Reykjanes Geothermal Field in the Oblique Rift of SW Iceland: From Regional to Reservoir Scales. Open Journal of Geology, 8, 
333-382. https://doi.org/10.4236/ojg.2018.83021

[81] Gawthorpe, R.L. and Hurst, M. (1993) Transfer Zones in Extensional Basins: Their Structural Style and Influence on Drainage Development and Stratigraphy. Journal of the Geological Society, London, 150, 1137-1152. https://doi.org/10.1144/gsjgs.150.6.1137

[82] Chorowicz, J. and Sorlien, C. (1992) Oblique Extensional Tectonics in the Malawi Rift, Africa. Geological Society of America Bulletin, 104, 1015-1023. https://doi.org/10.1130/0016-7606(1992)104<1015:OETITM>2.3.CO;2

[83] Legg, M.R., Goldfinger, C., Kamerling, M.J., Chaytor, J.D. and Einstein, D.E. (2007) Morphology, Structure and Evolution of California Continental Borderland Restraining Bends. Geological Society, London, Special Publications, 290, 143-168. https://doi.org/10.1144/SP290.3

[84] Segall, P. and Pollard, D.D. (1983) Nucleation and Growth of Strike Slip Faults in Granite. Journal of Geophysical Research, 88, 555-568. https://doi.org/10.1029/JB088iB01p00555

[85] Kim, Y.S., Peacock, D.C.P. and Sanderson, D.J. (2004) Fault Damage Zones. Journal of Structural Geology, 26, 503-517. https://doi.org/10.1016/j.jsg.2003.08.002

[86] Wolfe, C.J., Bjarnason, I.Th., VanDecar, J.C. and Solomon, S.C. (1997) Seismic Structure of the Iceland Mantle Plume. Nature, 385, 245-247. https://doi.org/10.1038/385245a0

[87] Bjarnason, I.Th. (2008) An Iceland Hotspot Saga. Jökull, 58, 3-16.

[88] White, R.S. and Mckenzie, D. (1989) Magmatism at Rift Zones: The Generation of Volcanic Continental Margins and Flood Basalts. Journal of Geophysical Research, 94, 7685-7729. https://doi.org/10.1029/JB094iB06p07685

[89] Saunders, A.D., Fitton, J.G., Kerr, A.C., Norry, M.J. and Kent, R.W. (1997) The North Atlantic Igneous Province. In: Mahoney, J.J. and Coffin, M.L., Eds., Large Igneous Provinces. Washington, D.C., American Geophysical Union Geophysical Monograph, Vol. 100, 45-93. https://doi.org/10.1029/GM100p0045

[90] McDougall, I., Saemundsson, K., Jóhannesson, H., Watkins, N.D. and Kristjánsson, L. (1977) Extension of the Geomagnetic Polarity Time Scale to 6.5 m.y.: K-Ar Dating, Geological and Paleomagnetic Study of a 3,500 m Lava Succession in Western Iceland. Bulletin of Geological Society of America, 88, 1-15. https://doi.org/10.1130/0016-7606(1977)88<1:EOTGPT>2.0.CO;2

[91] Vogt, P.R., Johnson, G.L. and Kristjansson, L. (1980) Morphology and Magnetic Anomalies North of Iceland. Journal of Geophysics, 47, 67-80.

[92] Brandsdóttir, B., Hooft, E.E.E., Mjelde, R. and Murai, Y. (2015) Origin and Evolution of the Kolbeinsey Ridge and Iceland Plateau, N-Atlantic. AGU, Geochemistry, Geophysics, Geosystems, 16, 612-634. https://doi.org/10.1002/2014GC005540

[93] DeMets, C., Gordon, R.G., Argus, D.F. and Stein, S. (1994) Effect of Recent Revisions to the Geomagnetic Reversal Time Scale on Estimates of Current Plate Motions. Geophysical Research Letters, 21, 2191-2194. https://doi.org/10.1029/94GL02118

[94] Hreinsdóttir, S., Einarsson, P. and Sigmundsson, F. (2001) Crustal Deformation at the Oblique Spreading Reykjanes Peninsula, SW Iceland: GPS Measurements from 1993 to 1998. Journal of Geophysical Research, 106, 13803-13816. https://doi.org/10.1029/2001JB000428

[95] Talwani, M., Windisch, C.C. and Langseth, M.G. (1971) Reykjanes Ridge Crest: A Detailed Geophysical Study. Journal of Geophysical Research, 76, 473-516. 
https://doi.org/10.1029/JB076i002p00473

[96] Parson, L.M., Murton, B.J., Searle, R.C., Booth, D., Evans, J., Field, P., Keeton, J., Laughton, A., McAllister, E., Millard, N., Redbourne, L., Rouse, I., Shor, A., Smith, D., Spencer, S., Summerhayes, C. and Walker, C. (1993) En Echelon Axial Volcanic Ridges at Reykjanes Ridge: A Life Cycle of Volcanism and Tectonics. Earth and Planetary Science Letters, 117, 73-87. https://doi.org/10.1016/0012-821X(93)90118-S

[97] Trippanera, D., Acocella, V., Ruch, J. and Abebe, B. (2015) Fault and Graben Growth along Active Magmatic Divergent Plate Boundaries in Iceland and Ethiopia. Tectonics, 34, 2318-2348. https://doi.org/10.1002/2015TC003991

[98] Vogt, P.R. (1971) Astenoshphere Motion Recorded by the Ocean Floor South of Iceland. Earth and Planetary Science Letters, 13, 153-160. https://doi.org/10.1016/0012-821X(71)90118-X

[99] Hey, R., Martinez, F., Höskuldsson, Á., Eason, D.E., Sleeper, J., Thordarson, S., Benediktsdóttir, Á. and Merkuryev, S. (2016) Multibeam Investigation of the Active North Atlantic Plate Boundary Reorganization Tip. Earth and Planetary Science Letters, 435, 115-123. https://doi.org/10.1016/j.epsl.2015.12.019

[100] Bodvarsson, G. and Walker, G.P.L. (1964) Crustal Drift in Iceland. The Geophysical Journal of the Royal Astronomical Society, 8, 285-300. https://doi.org/10.1111/j.1365-246X.1964.tb06295.x

[101] Sæmundsson, K. (1978) Fissure Swarms and Central Volcanoes of the Neovolcanic Zones of Iceland. In: Bowes, D.R. and Leake, B.E., Eds., Crustal Evolution in Northwestern Britain and Adjacent Regions, Geological Journal, Special Issue, Vol. 10, 415-432.

[102] Bodvarsson, G. (1961) Physical Characteristics of Natural Heat Resources in Iceland. Jökull, 11, 29-38.

[103] Tryggvason, E. (1959) Earthquakes in Iceland during the Years 1956, 1957, 1958. Náttúrufræðingurinn, 29, 84-91, Reykjavik (in Icelandic).

[104] Ward, P.L. (1971) New Interpretation of the Geology of Iceland. Geological Society of America Bulletin, 82, 2991-3012. https://doi.org/10.1130/0016-7606(1971)82[2991:NIOTGO]2.0.CO;2

[105] McMaster, R.L., Schilling, J.G.E. and Pinet, P.R. (1977) Plate Boundary within Tjörnes Fracture Zone on Northern Iceland's Insular Margin. Nature, 269, 663-668. https://doi.org/10.1038/269663a0

[106] Jakobsdóttir, S.S. (2008) Seismicity in Iceland: 1994-2007. Jökull, 58, 75-100.

[107] Einarsson, P. (1979) Seismicity and Earthquake focal Mechanisms along the mid-Atlantic Plate Boundary between Iceland and the Azores. Tectonophysics, 55, 127-153. https://doi.org/10.1016/0040-1951(79)90338-X

[108] Rögnvaldsson, S., Gudmundsson, A. and Slunga, R. (1998) Seismotectonic Analysis of the Tjörnes Fracture Zone, an Active Transform Fault in North Iceland. Journal of Geophysical Research, 103, 30117-30129. https://doi.org/10.1029/98JB02789

[109] Sigurðsson, H. (1970) Structural Origin and Plate Tectonics of the Snæfellsnes Volcanic Zone, Western Iceland. Earth and Planetary Science Letters, 10, 129-135. https://doi.org/10.1016/0012-821X(70)90074-9

[110] Jakobsson, S.P. (1972) Chemistry and Distribution Pattern of Recent Basaltic Rocks in Iceland. Lithos, 5, 365-386. https://doi.org/10.1016/0024-4937(72)90090-4

[111] Einarsson, P., Klein, F.W. and Björnsson, S. (1977) The Borgarfjörður Earthquakes 
in West Iceland 1974. Seismological Society of America Bulletin, 67, 187-208.

[112] Sæmundsson, K. (1979) Outline of Geology of Iceland. Jökull, 29, 7-28.

[113] Helgason, J. (1984) Frequent Shifts of the Volcanic Zone in Iceland. Geology, 12, 212-216. https://doi.org/10.1130/0091-7613(1984)12<212:FSOTVZ>2.0.CO;2

[114] Harðarson, B.S., Fitton, J.G., Ellam, R.M. and Pringle, M.S. (1997) Rift Relocation-A Geochemical and Geochronological Investigation of a Paleo-Rift in Northwest Iceland. Earth and Planetary Science Letters, 153, 181-196. https://doi.org/10.1016/S0012-821X(97)00145-3

[115] Schäfer, K. (1972) Transform Faults in Iceland. Geologische Rundschau, 61, 942-960. https://doi.org/10.1007/BF01820899

[116] Khodayar, M. and Einarsson, P. (2002) Strike-Slip Faulting, Normal Faulting, and Lateral Dike Injections along a Single Fault: Field Example of the Gljúfurá Fault near a Tertiary Oblique Rift-Transform Zone, Borgarfjörður, West Iceland. Journal of Geophysical Research, 107, ETG 5-1-ETG 5-16 (16 p).

https://doi.org/10.1029/2001JB000150

[117] Jancin, M., Young, K.D., Voight, B., Aronson, J.L. and Saemundsson, K. (1985) Stratigraphy and K/Ar Ages across the West Flank of the Northeast Iceland Axial Rift Zone, in Relation to the $7 \mathrm{Ma}$ Volcano-Tectonic Reorganization of Iceland. Journal of Geophysical Research, 90, 9961-9985. https://doi.org/10.1029/JB090iB12p09961

[118] Magnúsdóttir, S., Brandsdóttir, B., Driscoll, N. and Detrick, R. (2015) Postglacial Tectonic Activity within the Skjálfandadjúp Basin, Tjörnes Fracture Zone, Offshore Northern Iceland, Based on High Resolution Seismic Stratigraphy. Marine Geology, 367, 159-170. https://doi.org/10.1016/j.margeo.2015.06.004

[119] Thors, K. (1982) Shallow Seismic Stratigraphy and Structure of the Southernmost Part of the Tjörnes Fracture Zone. Jökull, 32, 91-105.

[120] Dauteuil, O., Bourgeois, O. and Mauduit, T. (2002) Lithosphere Strength Controls Oceanic Transform Zone Structure: Insights from Analogue Models. Geophysical Journal International, 150, 706-714. https://doi.org/10.1046/j.1365-246X.2002.01736.x

[121] Kristjánsson, L. (2008) Paleomagnetic Research on Icelandic Lava Flows. Jökull, 58, 101-116.

[122] Gaina, C., Nasuti, A., Kimbell, G.S. and Blischke, A. (2017) Break-Up and Seafloor Spreading Domains in the NE Atlantic. In: Péron-Pinvidic, G., Hopper, J.R., Stoker, M.S., Gaina, C., Doornenbal, J.C., Funck, T. and Árting U.E., Eds., The NE Atlantic Region: A Reappraisal of Crustal Structure, Tectonostratigraphy and Magmatic Evolution, Geological Society London, Special Publications, Vol. 447, 393-417. https://doi.org/10.1144/SP447.12

[123] Sæmundsson, K. (1974) Evolution of the Axial Rifting Zone in Northern Iceland and the Tjörnes Fracture Zone. Geological Society of America Bulletin, 85, 495-504. https://doi.org/10.1130/0016-7606(1974)85<495:EOTARZ>2.0.CO;2

[124] Garcia, S., Arnaud, N.O., Angelier, J., Bergerat, F. and Homberg C. (2003) Rift Jump Process in Northern Iceland since $10 \mathrm{Ma}$ from ${ }^{40} \mathrm{Ar} /{ }^{39} \mathrm{Ar}$ Geochronology. Earth and Planetary Science Letters, 214, 529-544. https://doi.org/10.1016/S0012-821X(03)00400-X

[125] Young, K.D., Jancin, M., Voight, B. and Orkan N.I. (1985) Transform Deformation of Tertiary Rocks along the Tjörnes Fracture Zone, North Central Iceland. Journal of Geophysical Research, 90, 9986-10010. https://doi.org/10.1029/JB090iB12p09986 
[126] Voight, B. and Mamula, N. (1983) Structure and Tectonics of Northeastern Iceland, In: Estes, J.E. and Thorley, G.A., Eds., Manual of Remote Sensing, 2nd Edition, Vol. 2, American Society of Photogrammetry, Falls Church, 1782-1786.

[127] Sæmundsson, K., Hjartarson, Á., Kaldal, I., Sigurgeirsson, M.Á., Kristinsson, S.G. and Víkingsson, S. (2012) Geological Map of Northern Volcanic Zone, Iceland. Northern Part. 1:100.000. Reykjavík, Iceland GeoSurvey and Landsvirkjun.

[128] Eiríksson, J. (1981) Lithostratigraphy of the Upper Tjörnes Sequence, North Iceland: The Breidavík Group. Acta Naturalia Islandica, 29, 37 p.

[129] Símonarson, L. and Eiríksson, J. (2008) Tjörnes - Pliocene and Pleistocene Sediments and Fauna. Jökull, 58, 331-342.

[130] Eiríksson, J., Guðmundsson, A.I., Kristjánsson, L. and Gunnarsson, K. (1990) Palaeomagnetism of Pliocene-Pleistocene Sediments and Lava Flows on Tjörnes and Flatey, North Iceland. Boreas, 19, 39-55. https://doi.org/10.1111/j.1502-3885.1990.tb00420.x

[131] Flóvenz, Ó.G. and Gunnarsson, K. (1991) Seismic Crustal Structure in Iceland and Surrounding Area. Tectonophysics, 189, 1-17. https://doi.org/10.1016/0040-1951(91)90483-9

[132] Gunnarsson, K., Kjartansson, E., Árnason, K., Abensour, D. and Kristoffersen, Y. (1996) Resource Exploration in Öxarfjörður: Seismic Reflection Surveys on the Öxarfjörður sand with Vibroseismic Method (in Icelandic). National Energy Authority, Report OS-96001/JHD-01, 49 p.

[133] Gunnarsson, K. (1998) Sedimentary Basins of the N-Iceland Shelf-Draft. National Energy Authority, Report OS-98014, 40 p.

[134] Richter, B., Brandsdóttir, B., Detrick, R., Helgadóttir, G., Kjartansson, E., Gunnarsson, K., Driscoll, N. and Kent, G. (2002) Indications of Hydrocarbons in the Tjörnes Basin, North Iceland. American Geophysical Union, Fall Meeting, Abstract \#OS71C-0306.

[135] Patton, H., Hubbard, A., Bradwell, T. and Schomacker, A. (2017) The Configuration, Sensitivity and Rapid Retreat of the Late Weichselian Icelandic Ice Sheet. Earth-Science Reviews, 166, 223-245. https://doi.org/10.1016/j.earscirev.2017.02.001

[136] Fenwick, R.A. (2010) Tectonic and Stratigraphic Evolution of the Tectonic and Stratigraphic Evolution of the Tjörnes Fracture Zone, Northern Iceland. PhD Thesis, University of California, San Diego, $177 \mathrm{p}$.

[137] Magnúsdóttir, S. (2013) Tectonics of the Skjálfandadjúp Basin, Tjörnes Fracture Zone. Master Thesis, University of Iceland, $64 \mathrm{p}$.

[138] Geirsson, H., Árnadóttir, Th., Völksen, Ch., Jiang, W., Sturkell, E., Villemin, Th., Einarsson, P., Sigmundsson, F. and Stefánsson, R. (2006) Current Plate Movements across the Mid-Atlantic Ridge Determined from 5 Years of Continuous GPS Measurements in Iceland. Journal of Geophysical Research, 111, B09407, 18 p.

[139] Metzger, S., Jónsson, S., Danielsen, G., Hreinsdóttir, S., Jouanne, F., Giardini, D. and Villemin, T. (2013) Present Kinematics of the Tjörnes Fracture Zone, North Iceland, from Campaign and Continuous GPS Measurements. Geophysical Journal International, 192, 441-455. https://doi.org/10.1093/gji/ggs032

[140] Halldórsson, P. (2005) Earthquake Activity in N-Iceland (in Icelandic). Icelandic Meteorological Office, Report 05021, 34 p.

[141] Stefánsson, R., Guðmundsson, G.B. and Halldórsson, P. (2008) Tjörnes Fracture zone. New and Old Seismic Evidences for the Link between the North Iceland Rift Zone and the Mid-Atlantic Ridge. Tectonophysics, 447, 117-126. 
https://doi.org/10.1016/j.tecto.2006.09.019

[142] Icelandic Meteorological Office (IMO), SIL Network, Earthquakes and Volcanic Data. http://en.vedur.is/earthquakes-and-volcanism/earthquakes

[143] Hjaltadóttir, S. and Vogfjörð, K. (2011) Fracture Mapping at Theistareykir and Bjarnarflag with High Resolution Location of Microearthquakes (in Icelandic). Landsvirkjun, Report, LV-2011-116, 44 p.

[144] Björnsson, A., Johnsen, G., Sigurðsson, S., Thorbergsson, G. and Tryggvason, E. (1979) Rifting of the Plate Boundary in North Iceland 1975-1978. Journal of Geophysical Research, 84, 3029-3038. https://doi.org/10.1029/JB084iB06p03029

[145] Sigmundsson, F., Hooper, A., Hreinsdottir, S., Vogfjörð, K.S., Ófeigsson, B.G., Heimisson, E.R., Dumont, S., Parks, M., Spaans, K., Gudmundsson, G.B., Drouin, V., Arnadottir, T., Jonsdottir, K., Gudmundsson, M.T., Hognadottir, T., Fridriksdottir, H.M., Hensch, M., Einarsson, P., Magnusson, E., Samsonov, S., Brandsdottir, B., White, R.S., Agustsdottir, T., Greenfield, T., Green, R.G., Hjartardottir, A.R., Pedersen, R., Bennett, R.A., Geirsson, H., La Femina, P.C., Bjornsson, H., Palsson, F., Sturkell, E., Bean, C.J., Mollhoff, M., Braiden, A.K. and Eibl, E.P.S. (2015) Segmented Lateral Dyke Growth in a Rifting Event at Bardarbunga Volcanic System, Iceland. Nature, 517, 191-195. https://doi.org/10.1038/nature14111

[146] Ágústsdóttir, Th., Woods, J., Greenfield, T., Green. R.G., White, R.S., Winder, T., Brandsdóttir, B., Steinthórsson, S. and Soosalu, H. (2016) Strike-Slip Faulting during the 2014 Bárðarbunga-Holuhraun Dike Intrusion, Central Iceland. Geophysical Research Letters, 43, 1495-1503. https://doi.org/10.1002/2015GL067423

[147] Khodayar, M. (2018) Shift of a Rift by a Transform Zone: Case from Northern Rift Zone and Tjörnes Fracture Zone of Iceland. Petroleum Geoscience, Thematic Set: Rifts III: Catching the Wave, The Geological Society of London and EAGE, First Published Online April 2018, 11 p. https://doi.org/10.1144/petgeo2016-132

[148] Georgsson, L.S., Friðleifsson, G.Ó., Ólafsson, M. and Flóvenz, Ó.G. (2000) The geothermal Exploration of the Öxarfjörður High-Temperature Area, NE Iceland. Proceedings World Geothermal Congress, Japan, 1157-1162.

[149] Gíslason, G., Johnsen, G.V., Ármannsson, H., Torfason, H. and Árnason, K. (1984) Theistareykir: Surface Exploration in the High-Temperature Field. National Energy Authority, Report OS-84089/JHD-16, 134 p, 3 Maps.

[150] Friðleifsson, G.Ó. (1994) Geothermal Gradient and Hydrothermal Systems off North Iceland. Short Report Orkustofnun, GÓF-94-05, 5 p.

[151] Hannington, M., Herzig, P., Stoffers, P., Scholten, J., Botz, R., Garbe-Schönberg, D., Jonasson, I. R. and Roest, W.; Shiphoard Scientific Party (2001) First Observations of High-Temperature Submarine Hydrothermal Vents and Massive Anhydrite Deposits off the North Coast of Iceland. Marine Geology, 177, 199-220. https://doi.org/10.1016/S0025-3227(01)00172-4

[152] Valtýsson, H. P., Bogason, E. and Eiríksson, B. (2013) The Hydrothermal Chimneys Eyjafjörður Underwater. Report The Fisheries Centre of the University of Akureyri, $95 \mathrm{p}$.

[153] Hjartarson, Á., Erlendsson, Ö. and Gautason, B. (2017) Marine Geology in Eyjafjörður: Multibeam Survey, Hydrothermal Vents, Tectonic, Avalanches, Channels, and Ship Wrecks (In Icelandic). Iceland GeoSurvey, Report ÍSOR-2017/053, 37 p.

[154] Richter, B. and Friðleifsson, G.Ó. (1999) Mapping and Analysis of Gases in Öxarfjörður. Short Report, National Energy Authority (Orkustofnun) BR-GÓF99/01, 11 p. 
[155] Richter, B., Brandsdottir, B., Geptner, A., Driscoll, N. and Boejesen-Koefoed, J. (2005) Hydrocarbon Prospect of the Tjornes Fracture Zone, North of Iceland. American Geophysical Union, Fall Meeting, Abstract \#OS33C-1487.

[156] Geptner, A., Richter, B., Pikovskii, Y.I., Chernyansky, S.S. and Alexeeva, T.A. (2006) Hydrothermal Polycyclic Aromatic Hydrocarbons in Marine and Lagoon Sediments at the Intersection between Tjörnes Fracture Zone and Recent Rift Zone (Skjálfandi and Öxarfjörður bays), Iceland. Marine Chemistry, 101, 153-165.

https://doi.org/10.1016/j.marchem.2006.02.004

[157] Richter, B. and Gunnarsson, K. (2010) Overview of Hydrocarbon Related Research in Tjörnes. Report Iceland GeoSurvey, ÍSOR-2010/007, Prepared for National Energy Authority, $24 \mathrm{p}$.

[158] Friðleifsson, G.Ó., Eiríksson, J., Hafliðason, H., Gunnarsson, K., Ólafsson, G., Thors, K., Larsen, B., Thórhallsson, S. and Sveinbjörnsdóttir, Á.E. (1994) ODP Proposal for Drillsites within the Tjörnes Fracture Zone Sedimentary Basin. Late Cainozoic Paleoceanography and Sedimentation History at the Arctic Boundary.

[159] Magnúsdóttir, S. and Brandsdóttir, B. (2011) Tectonics of the Theistareykir Fissure Swarm. Jökull, 61, 65-79.

[160] Hjartardóttir, Á.R., Einarsson, P., Magnúsdóttir, S., Björnsdóttir, P. and Brandsdóttir, B. (2016) Fracture Systems of the Northern Volcanic Rift Zone, Iceland-An Onshore Part of the Mid-Atlantic Plate Boundary. In: Wright, T.J., Ayele, A., Ferguson, D.J., Kidane, T. and Vye-Brown, C., Eds., Magmatic Rifting and Active Volcanism. Geological Society, London, Special Publications, Vol. 420, 297-314. First Published Online January 28, 2015.

[161] Erlendsson, Ö. and Hjartarson, Á. (2016) Map of Geological Hazards on Iceland Shelf. 2016 Spring Meeting of the Icelandic Geosciences Society, Reykjavík, 34-35.

[162] EMODnet-European Marine Observation and Data Network (2016) Chapter 3.6, Workpackage 6, Geological Events and Probabilities. Fig. 26, p. 55. In: Thematic Lot n 2 GEOLOGY, Phase 2-Final Report 2013-2016, 120 p.

[163] Brandsdóttir, B., Richter, B., Riedel, C., Dahm, T., Helgadóttir, G., Kjartansson, Detrick, R.S., Magnússon, A., Ásgrímsson, A.L., Pálsson, B.H., Karson, J., Sæmundsson, K., Mayer, L.A., Calder, B.R. and Driscoll, N. (2004) Tectonic Details of the Tjörnes Fracture Zone, an Onshore-Offshore Ridge-Transform in N-Iceland. American Geophysical Union Fall Meeting, EOS Transactions, 85, F1071, Poster.

[164] Tibaldi, A., Bonali, F.B. and Pasquaré Mariotto, F.A. (2016) Interaction between Transform Faults and Rift Systems: A Combined Field and Experimental Approach. Frontier in Earth Science, 4, 33. https://doi.org/10.3389/feart.2016.00033

[165] Riedel, C., Schmidt, M., Botz, R. and Theilen, F. (2001) The Grimsey Hydrothermal Field Offshore North Iceland: Crustal Structure, Faulting and Related Gas Venting. Earth and Planetary Science Letters, 193, 409-421. https://doi.org/10.1016/S0012-821X(01)00519-2

[166] Lupi, M., Geiger, S. and Graham, C.M. (2010) Hydrothermal Fluid Flow within a Tectonically Active Rift-Ridge Transform Junction: Tjörnes Fracture Zone, Iceland. Journal of Geophysical Research, 115, B05104, 17 p.

[167] Khodayar, M., Björnsson, S., Karlsdóttir, R., Ágústsson, K. and Ólafsson, M. (2015) Tectonic Control of Alteration, Gases, Resistivity, Magnetics and Gravity in Theistareykir Area. Implications for Northern Rift Zone and Tjörnes Fracture Zone. Iceland GeoSurvey, Report ÍSOR-2015/002, LV-2015-039, 59 p., 2 Maps.

[168] Khodayar, M., Björnsson, S., Kristinsson, S.G., Karlsdóttir, R. and Ólafsson, M. 
(2015) Multidisciplinary Structural Analysis and Drilling Targets at Theistareykir, Northern Rift Zone and Tjörnes Fracture Zone. Iceland GeoSurvey, Report ÍSOR-2015/0043, LV-2015-0135, 49 p., 1 Map.

[169] Khodayar, M., Björnsson, S., Kristinsson, S.G., Karlsdóttir, R., Ólafsson, M. and Víkingsson, S. (2018) Tectonic Control of the Theistareykir Geothermal Field by Rift and Transform Zones in North Iceland: A Multidisciplinary Approach. Open Journal of Geology, 8, 543-584. https://doi.org/10.4236/ojg.2018.86033

[170] Karlsdóttir, R., Vilhjálmsson, A.M., Árnason, K. and Beyene, A.T. (2012) Peistareykir Geothermal Area, Northern Iceland. 3D Inversion of MT data. Iceland GeoSurvey, Report ÍSOR-2012/046, 173 p.

[171] Walker, G.P.L. (1963) The Breiddalur Central Volcano, Eastern Iceland. Quaternary Journal Geological Society of London, 119, 29-63. https://doi.org/10.1144/gsjgs.119.1.0029

[172] Khodayar, M. and Björnsson, S. (2013) Preliminary Fracture Analysis of Theistareykir Geothermal Field and Surroundings, Northern Rift Zone and Tjörnes Fracture Zone. Iceland GeoSurvey, Report ÍSOR-2013/029, 57 p., 2 Maps.

[173] Garcia, S. and Dhont, D. (2005) Structural Analysis of the Húsavík-Flatey Transform Fault and Its Relationships with the Rift System in Northern Iceland. Geodinamica Acta, 18, 31-41. https://doi.org/10.3166/ga.18.31-41

[174] Hjartarson, Á., Blischke, A. and Erlendsson, Ö. (2014) The North Iceland Shelf, Chapter 7.6.3, pp. 188-189. In: Hopper, J.R., Funck, T., Stoker, M.S., Árting, U., Peron-Pinvidic, G., Doornenbal, H. and Gaina C., Eds., Tectonostratigraphic Atlas of the North-East Atlantic Region, GEUS, Copenhagen.

[175] Tucholke, B. (1988) Sediment Distribution. In: Srivastava, S.P., Voppel, D. and Tucholke, B., Eds., Geophysical Atlas of the North Atlantic between $50^{\circ}$ to $72^{\circ} \mathrm{N}$ and $0^{\circ}$ to $65^{\circ} \mathrm{W}$, Deutsches Hydrographisches Institut, Hamburg, 9-12.

[176] Khodayar, M. and Einarsson, P. (2004) Reverse-Slip Structures at Oceanic Diverging Plate Boundaries and Their Kinematic Origin: Data from Tertiary Crust of West and South Iceland. Journal of Structural Geology, 26, 1945-1960. https://doi.org/10.1016/j.jsg.2004.06.001

[177] Hensch, M., Riedel, C., Reinhardt, J. and Dahm, T.; The NICE-People (2008) Hypocenter Migration of Fluid-Induced Earthquake Swarms in the Tjörnes Fracture Zone (North Iceland). Tectonophysics, 447, 80-94. https://doi.org/10.1016/j.tecto.2006.07.015

[178] Ágústsson, K. and Guðnason, E.Á. (2016) Focal Mechanism Solutions of Selected Earthquakes in Theistareykir (in Icelandic). Iceland GeoSurvey, Short Report ÍSOR-16032, 5 p.

[179] Wright, T.J., Sigmundsson, F., Pagli, C., Belachew, M., Hamling, I.J., Brandsdóttir, B., Keir, D., Pedersen, R., Ayele, A., Ebinger, C., Einarsson, P., Lewi, E. and Calais, E. (2012) Geophysical Constraints on the Dynamics of Spreading Centres from Rifting Episodes on Land. Nature Geoscience, 5, 242-250. https://doi.org/10.1038/ngeo1428

[180] Einarsson, P. and Brandsdóttir, B. (1980) Seismological Evidence for Lateral Magma Intrusion during the 1978 Deflation of the Krafla Volcano in NE Iceland. Journal of Geophysics, 47, 160-165.

[181] Tryggvason, E. (1984) Widening of the Krafla Fissure Swarm during the 1975-1981 Volcano-Tectonic Episode. Bulletin of Volcanology, 47, 47-69. https://doi.org/10.1007/BF01960540 
[182] Angelier, J., Bergerat, F. and Homberg, C. (2000) Variable Coupling across Weak Oceanic Transform Fault: Flateyjarskagi, Iceland. Terra Nova, 12, 97-101. https://doi.org/10.1046/j.1365-3121.2000.123279.x

[183] Garcia, S., Angelier, J., Bergerat, F. and Homberg, C. (2002) Tectonic Analysis of an Oceanic Transform Fault Zone Based on Fault-Slip Data and Earthquake Focal Mechanisms: The Húsavík-Flatey Fault Zone, Iceland. Tectonophysics, 344, 157-174. https://doi.org/10.1016/S0040-1951(01)00282-7

[184] Ziegler, M., Rajabi, M., Heidbacha, O., Hersir, G.P., Ágústsson, K., Árnadóttir, S. and Zang, A. (2016) The Stress Pattern of Iceland. Tectonophysics, 674, 101-113. https://doi.org/10.1016/j.tecto.2016.02.008

[185] Davatzes, N.C. and Hickman, S.H. (2006) Stress and Faulting in the Coso Geothermal Field: Update and Recent Results from the East Flank and Coso Wash. Proceedings, $31^{\text {st }}$ Workshop on Geothermal Reservoir Engineering, Stanford University, California, SGP-TR-179, 12 p.

[186] Brandsdóttir, B., Detrick, R., Helgadóttir, G., Kjartansson, E., Richter, B., Gunnarsson, K., Guðlaugsson, S.P. and Driscoll, N. (2002) A New Perspective on the Tectonics of the Tjörnes Fracture Zone, Offshore Northern Iceland, from EM300 Multibeam Bathymetry, High Resolution MCS and CHIRP. American Geophysical Union Fall Meeting Abstract, OS71C-0313.

[187] Brandsdóttir, B. (2013) Tjörnes Fracture Zone (in Icelandic). In: Sólnes, J., Sigmundsson, F. and Bessason, B., Eds., Natural Hazards in Iceland, Volcanic Eruptions and Earthquakes, Viðlagatrygging Îslands-Háskólaútgáfan, Reykjavík, 551-554. 